\title{
Assessing the Effects of the Mexican Drug War on Economic Growth: an Empirical Analysis
}

\author{
GERMÀ BEL AND MAXIMILIAN HOLST
}

\section{Forthcoming in Southern Economic Journal}

RUNNING HeAD: The Mexican Drug War and Economic Growth

\section{AfFiliationS:}

Germà Bel. Department of Econometrics, Statistics and Applied Economics. Universitat de Barcelona. John M. Keynes 1-11. 08034 Barcelona, Spain. Tel: +34934021946; Fax: +34934024573; e-mail: gbel@ub.edu Maximilian Holst (Corresponding author). Department of Econometrics, Statistics and Applied Economics. Universitat de Barcelona. John M. Keynes 1-11. 08034 Barcelona, Spain. Tel: +34934029010; Fax: +34934024573; e-mail: maximilian.holst@ub.edu

JEL CODES: H56, K42, R11

ACKNOWLEDGMeNTs: We thank the Spanish Ministry of Economy and Competitiveness (project ECO2016-76866R) and the Catalan government (SGR2014-325; 2017 SGR 644) for financial support. None of the funding sources was involved in any stages of this research. We are thankful for comments and suggestions received when a previous version of this paper was presented at the First Catalan Economic Society Conference (May, 2017). 


\begin{abstract}
Mexican President Felipe Calderón took office in December 2006. From the outset, his government deployed an aggressive security policy to fight drug trafficking organizations in what became known as the 'Mexican Drug War.' The policy earned considerable criticism since a heavy number of unintended casualties resulted from the frontal assault waged against the drug cartels. In this article, we evaluate the effects of the Mexican Drug War on Mexican states' economic growth. To do so, we study the effects of the rise in the homicide rate and changes in a state-level approximation of the military budget on economic growth. Using dynamic panel data econometrics, we find that while the growth in the number of homicides had negative and significant effects on state GDP growth, state military expenditures aimed at fighting drug trafficking had a positive and significant effect on the per capita economic growth rate.
\end{abstract}




\section{Introduction}

At the end of 2006, Felipe Calderón's government declared a war on drug trafficking organizations (DTOs), ${ }^{1}$ and ordered the military to take strong action against the drug cartels. The military initiated a series of operations targeting the most dangerous drug criminals in Mexico. However, the criminals fought back, resulting in thousands of casualties (including, criminals, police, the military, and civil population). Indeed, the detention and eventual killing of the drug lords left a power vacuum that rival organizations sought to fill, which further increased the number of victims.

From the 1990s through to the mid-2000s, Mexico's homicide rate had fallen to an alltime low by 2007 of 8.1 homicides per 100,000 inhabitants (an absolute total of 8,861). Shirk and Wallman (2015) claim that if the fall had continued, the homicide rate would have eventually reached similar levels to those in the United States (five homicides per 100,000 inhabitants). However, the homicide rate increased dramatically, reaching a high of 23.0 homicides per 100,000 inhabitants in 2011. The Mexican National Statistics Institute (INEGI) recorded 121,613 homicides in the country during Calderón's administration, while during Vicente Fox's preceding administration (2001-2006) the number of homicides was less than half $(60,162)$. When Calderón left office, the homicide rate fell slightly for a time, but recently it has risen again. Indeed, since the end of Calderón's administration in 2012, the strategy to fight DTOs has not changed significantly.

\footnotetext{
${ }^{1}$ The U.S. National Drug Threat Assessment defines DTOs as “complex organizations with highly defined command-and-control structures that produce, transport, and/or distribute large quantities of one or more illicit drugs." (DOJ 2010, p.10).
} 
Although there are barely any studies analyzing the impact of this spiraling violence on GDP, evidence suggests that foreign direct investment (FDI) experienced a setback in some industries (e.g. Mining and Oil Extraction) (Ashby and Ramos 2013). However, this study analyzed all Mexican states together, regardless of whether they presented signs of DTO violence, and so the setback may be attributable to other factors. Yet, firms and individuals settled in dangerous regions have opted to move away to safer areas. According to NRC/IDMC (2010), 230,000 people are estimated to have fled their homes (up to 2010). Moreover, various countries have issued recommendations to their citizens not to visit certain areas of Mexico (Zapata 2011). But whether these factors have affected the GDP growth rate has yet to be analyzed.

Economic variables seem likely to be linked closely to the violence problem. Terrorist acts, such as those perpetrated in Spain, Turkey and Israel, have shown that economies suffer major setbacks from violence. While the terrorism-related literature can serve as a point of reference here, we cannot apply its findings to the case of DTO violence in Mexico, as terrorism and drug trafficking are very different in nature.

Based on the number of victims during Mexico's recent drug crusade and the opportunity costs of government spending on its fight against DTOs, it is reasonable to expect that Mexico's economy was affected by DTO activities. A society that experiences violent acts faces not only the costs suffered by those directly and indirectly affected, but also the political and institutional costs. Acemoglu et al. (2013) point out that when the relationship between the actors controlling institutions and criminals reaches certain levels, a symbiotic relationship may emerge and nonstate actors are able to influence policy decisions. Events in Italy illustrate how criminal organizations like the Mafias have poisoned and corrupted government at the highest levels 
(Alesina et al. 2016), while Colombia faced the same problem up until the end of the 20th century, when the drug cartels of Medellin and Cali were particularly strong.

A number of studies have analyzed the economic effects of drug-related violence, but what we do in this article is to assess the specific impact of President Calderón's policy aimed at fighting DTOs and drug-related violence. To do so, we analyze the effects of increases in drugrelated violence (based on crime rates) and a state-level approximation of the military budget on the growth of state GDP per capita. For this purpose, we work in a well-known growth setting, using the $\beta$-convergence framework, while also considering the possibility of spatial effects between states. The objective of this paper is to assess not only how violence deterred economic activity, but more importantly how government action in the form of military expenditure affected state economic growth.

To analyze the impact of military expenditure, we approximate state-level army budgets, and allocate them based on the crime variables associated with the drug cartels and the fight against DTOs. Military spending is to be understood as the army expenditure only, and does not include navy or air force expenditure.

Thus, we make several contributions to the literature: 1) we study how the 'Drug War' policy affected economic growth in the Mexican states. Although the effects of the violence escalated, we focus on the actions implemented by the central government, specifically in the form of military expenditure, to tackle the problem of DTOs in the territory. To the best of our knowledge, the impact of state-level military spending on the per capita GDP growth rate, against the backdrop of the Mexican Drug War, has never been analyzed before. 2) By using the $\beta$-convergence framework, as developed within economic theory, and by employing dynamic panel data, for the empirical analysis, we build upon existing efforts to assess the effects of 
violence generated by the presence of DTOs and government attempts to fight drug criminals. In so doing, we link the empirical analysis of national security policy with economic theory in a more effective way than previous studies examining violence and economic growth in Mexican states that fail to consider the dynamic nature of the data. 3) Our approach captures the violence generated by the presence of DTOs by employing a range of different variables. We also make several approximations of military spending at the state level, given that such information is not publicly available in Mexico. To overcome this limitation, we develop a new method to estimate military expenditure at the state level in a developing country. By using a range of options for both variables, we are able to endow our analysis with greater robustness.

\section{Literature Review}

\section{Literature related to Economic Growth in Mexico}

The analysis we undertake of the effects of military expenditure on economic growth in the context of the Drug War policy is based on a growth model, and several studies in the literature are of particular relevance to the case we present. The speed of convergence of an economy does not always remain the same. There will be periods in which convergence accelerates and others in which it slows down. Similarly, regional economies within a country may grow at different speeds, leading to convergence or divergence.

Chiquiar (2005), in a study of income convergence across Mexican states, suggests that the divergence pattern that emerged in the mid-1980s was not reversed with the signing of NAFTA, and that Mexican regions became more sensitive to new sources of growth. Likewise, for this same period, Rodríguez-Oreggia (2005) contends that differences in growth across states can be attributed to disparities in human capital, with northern and central states boasting higher 
skilled workers than those found in Mexico's southern states. Carrion-i-Silvestre and GermanSoto (2007) took a time series from 1940-2001 and found evidence of convergence after controlling for structural breaks. In a more recent study, Cabral and Mollick (2012), using dynamic panel data techniques, found positive rates of output convergence across Mexican regions: $9.4 \%$ for the period 1996 to 2006 .

All these studies analyzed periods of time prior to the Mexican Drug War, which was initiated in 2007. It is our conjecture that the speed of convergence might have changed for those Mexican states that were most affected by the policy outcomes (i.e. drastic increase in the homicide rate).

\section{Literature related to Drug Trafficking Organizations}

A difficulty when fighting DTOs is that the actions undertaken by governments often just shift the problem to another location. The spatial competition model developed by Rasmussen et al. (1993) suggests that higher drug enforcement in one jurisdiction simply moves the drug problem to neighboring jurisdictions, resulting in higher violent crime rates. Their analysis concludes that "Drug enforcement increases violent crime due to the disruption of spatial equilibria in drug markets" (Rasmussen et al. 1993, pp. 229-30).

In countries facing insurgency movements, governments seek to fight the insurgents by military means and by providing services to incentivize the community to share information. Berman et al. (2011) examined the case of Iraq and found that regional spending on public goods is violence-reducing. However, Andreas (2004, p. 650) argues that "[m]ilitary success on the battlefield can significantly depend on entrepreneurial success in the illicit economy [...]". 
The economic literature on DTOs is scarce. Several scholars have opted to place the violent acts happening in Mexico in the same category as terrorist or counter-insurgency acts. As Williams (2012) explains, this characterization is wrong, since the killings in Mexico are not motivated by politics, ideology or religion and he stresses that while there is some evidence of 'careless' violence (some civilians have been erroneously executed or caught in the crossfire), the violence in Mexico has been quite selective.

The reasons for violence in Mexico are diverse. Variables such as the poverty rate, unemployment and weak institutions all play an important role. For example, Levitt and Venkatesh (2000) find that criminal organizations are more successful at recruiting people with lower incomes. In Mexico, where DTOs have been active for decades, the reasons for the rise in the homicide rate appear to be more closely associated with the increase in reprisal killings, the wars waged between rival DTOs and clashes with the armed forces. Rios (2013) claims that the violence is driven by two mechanisms: 1) the competition between DTOs to expand their drug trafficking turf, and 2) government action in the form of police and military operations to apprehend drug cartel members. These two mechanisms are obviously interconnected, since when the leaders of a dominant DTO are arrested, its competitors see an opportunity to expand into their territory, with a resulting escalation in violence.

A recent study investigating violence and the effects of DTOs in Mexico (Dell 2015) shows that drug-related violence increases substantially after closely fought mayoral elections 
involving a change in the ruling party. ${ }^{2}$ This result is in line with the findings of Snyder and Duran-Martinez (2009), Astorga and Shirk (2010) and Chabat (2010). A wave of violence following a change in the ruling party at the municipal level seems to indicate that the previous incumbent had entered into agreements with DTOs. Following the elections, these agreements are no longer binding and, as the police and military forces seek to capture the drug lords, violence breaks out. The Italian mafia display a similar pattern of behavior: "regions with a greater presence of criminal organizations are characterized by abnormal increases in homicides during the year before elections" (Alesina et al. 2016, p.2).

\section{Literature related to Economic Effects of Drug Violence}

Several studies have looked at economic variables and how the presence of organized crime affects them. For instance, Cabral et al. (2016) report that a rise in crime has negative effects on labor productivity. Ashby and Ramos (2013) find that organized crime in Mexico deters FDI in financial services, commerce and agriculture. For the housing market, the findings in Ajzenman et al. (2015) indicate that an increase of drug related homicides has negative effects on lowquality housing prices. In terms of human capital accumulation, Marquez-Padilla et al. (2015) report barely any effect on total enrollment in schools. In their analysis of income inequality, Enamorado et al. (2016) estimate that a one-point increase in the Gini coefficient increases the number of drug-related homicides by $36 \%$. Finally, Orozco-Aleman and Gonzalez-Lozano

\footnotetext{
${ }^{2}$ Our analysis also included a test of political changes at the state level. Several dummy variables were used to test whether states governed by PRI or by PAN showed abnormal increases in their crime variables after state elections. None of the results was significant. Results are available upon request.
} 
(2017) study migration flows and find that migration decisions are sensitive to both local violence and transit (on route) violence.

However, other studies conclude that the presence of DTOs could have various "positive" effects for the local economy. In their bid to expand their influence, DTOs need to infiltrate the social structure and attract members of the local community into the ranks that make up what is a labor-intensive drug production chain (Rios 2008). Having a DTO in town can lead to higher rates of employment and higher wages for those involved in production, transport and distribution. Fernández-Menéndez and Ronquillo (2006) report that farmers involved in marijuana and poppy production can earn wages that are several times higher than normal, in addition to receiving a generous lump-sum payment. Likewise, anecdotal evidence suggests that DTOs can have a positive economic impact: "The narcoeconomy ushered certain forms of consumption into an otherwise stagnant, marginal community; it brought money back into the community in various forms of legal reinvestment activities, such as farms and businesses; and it provided many people with all manner of jobs.” (McDonald 2005, p. 121).

A further consequence of a town's being under the influence of a DTO might be that corrupt government agents work for the benefit of the DTO, accepting bribes and sabotaging police operations. Meanwhile, these corrupt agents have to launder their bribe money without raising suspicions. Moreover, by focusing federal police or military operations within a specific state means that federal police forces and soldiers have to be relocated to that state, with the resulting additional expenditure for the government.

To the best of our knowledge, the effects of the Mexican Drugs War on the country's GDP and income growth have been examined primarily in three studies. First, Robles et al. (2013) use electricity bills as a GDP proxy to estimate the impact of violence on GDP and 
unemployment using IV and Synthetic Control methods. They find that an increase of 10 homicides per 100,000 habitants results in an increase of around $1.5 \%$ in the rate of unemployment, a $0.4 \%$ reduction in the proportion of business owners, and a $1.2 \%$ reduction in average income. In addition, they use a synthetic control to estimate that electricity consumed per capita fell in the first 2 years after a conflict involving two DTOs.

Second, Pan et al. (2012) use a spatial model to estimate the impact of violence on GDP between 2005 and 2009. They find that while GDP growth is positively related to crime within a specific state in the previous year, it is negatively related to crime in its surrounding states. An interesting aspect of this study is the introduction of an aggregate variable of federal grants (education, public security, health services, and social infrastructure). The model specification features homicides and an aggregate crime variable, which includes "homicide, fraud, rape, assault, damage to property, theft, and other crimes" (Pan et al. 2012, p. 55). While the homicides variable shows no significant results, this crime variable yields positive effects on growth, suggesting that more crime would result in a higher growth rate of the economy (which goes against our intuition). The positive sign reported in their study could be caused by an overly generic aggregation of crime variables (some crimes might not be related to DTOs).

Third, Enamorado et al. (2014) employ the $\beta$-convergence framework to estimate the impact of drug-related homicides on real income growth in Mexico. They find evidence of a negative impact of drug-related homicides on income growth in Mexican municipalities between 2005 and 2010. Their model considers aggregate figures of public expenditure at the local level, which are found to be significant. When comparing the effects of drug-related homicides with those of non-drug-related homicides, they obtain negative and significant results for the drug- 
related homicide rate. The model recognizes some form of spatial interaction since it clusters the standard errors by state.

These last two studies are particularly relevant to the case we deal with here as both approaches seek to link their empirical models to the growth literature in a similar way to the method we adopt here. However, our analysis differs from these two studies in various ways. We seek to undertake a more comprehensive analysis of the Drug War in Mexico than previous studies by including an approximation of military expenditure instead of using federal grants (Pan et al. 2012) and municipal government expenditure (Enamorado et al. 2014). Figure 1 presents both grant expenditures destined for public security as a share of total grant expenditures and public security expenditures (i.e., local police) as a share of total municipal expenditures. Both public expenditure measures show that only an average of $1.4 \%$ of grant money and $3.9 \%$ of municipal expenditure are destined specifically to public security. These percentages suggest that the expenditure figures used by Pan et al. (2012) and Enamorado et al. (2014) are not earmarked to fight DTOs, while a key feature of our study is that we explicitly model the Mexican government's policy to fight DTOs by including military expenditure.

\section{(Insert FIGURE 1 around here)}

Other differences concern choices regarding the empirical methodology and data employed. Enamorado et al. (2014) opt for ordinary least squares and two-stage least squares in conducting their cross-sectional analysis, whereas Pan et al. (2012) use a spatial model with panel data. Neither of these models is dynamic. Here, by employing a difference-generalized method of moments (GMM) model, we take into account the dynamic nature of the data, and control for autocorrelation. This model is also well suited to deal with potential endogeneity issues. The range of our data is also greater than that drawn on in these two previous studies, 
which only analyze the initial stages of the spike in violence. By considering data from 2003 to 2013, we cover all of Calderón's presidency (and several years before).

In the absence of the policy implemented by Calderón's administration, it is likely that the homicide rate, in common with other crime indicators, would have followed the downward trend and eventually abated. However, the violence of this period was generated by a) the confrontation between government officials and DTO members; b) the struggles that broke out between DTO lieutenants as they fought to take power following the death of a DTO leader; and c) the expansion of turf boundaries by a DTO and the ensuing struggle for power with a competing DTO.

To enhance the measurement of crime indicators related to DTOs, we gave individual consideration to a range of high-impact crime variables. Indeed, these were the variables used by the government to assess progress during the Drug War. Government expenditure on the fight against crime is central to our model, since we wish to identify the effect of this spending on the state economy. Therefore, we concentrate on an approximation of state-level military budgets.

\section{The Policy}

During the last decade of the 20th century, the number of DTOs increased as a result of cartel fragmentation, an increase in political competition, and anti-corruption reforms (Snyder and Duran-Martinez 2009, p. 270). The growth of DTOs across the country weakened the government's position, even had they wanted to strike a new deal with the drug lords.

Towards the end of Fox's administration (2001-2006), DTO-related homicides rose significantly, from 9,329 in 2004 to 10,452 in 2006. Unsurprisingly, one of the main pillars of Calderón's campaign was to strengthen the rule of law, given that to continue tolerating DTOs 
would have represented too high a political cost (Chabat 2010). In December 2006, Calderón launched the 2007-2012 Directive for the Integral Fight against Drug Trafficking (Directiva para el Combate Integral al Narcotráfico 2007-2012).

While the Mexican military had played some role in fighting the DTOs for some time, the Directive introduced new and more aggressive guidelines against drug trafficking. It identified four strategies to support its national security policy: 1) Improve operation schemes to eradicate local cultivations, intercept illegal drug trafficking, and fight DTOs; 2) Contribute to activities organized by public security institutions to guarantee a safe social environment; 3) Help maintain the rule of law by fighting armed criminal organizations; 4) Strengthen army and air force capacities to enforce laws against firearms and explosives. This fourth point aimed at identifying and stopping the illegal firearm flows coming from the United States.

With the new Directive, "[t]he federal government [...] deployed thousands of federal troops to man checkpoints, establish street patrols, and oversee other domestic law enforcement functions in high drug violence states" (Shirk 2012, p. 10). In addition, the military inspected hangars, deposits, mail delivery companies, and bus and train stations. The military also cooperated with police forces to stop criminals. As Dell (2015) explains, "Drug seizures and high-level arrests are typically made by the federal police and military, who have the requisite training and weaponry to fight heavily armed traffickers” (p.1746). During Calderón’s administration, the Defense Department reported the detention of 9 high-ranking drug lords and 149 cartel lieutenants (Defense Department's activities reports, 2007-2012). ${ }^{3}$

\footnotetext{
${ }^{3}$ The fight against the drug cartels was not conducted by army forces alone. In fact, Calderón deployed the army, navy, and federal police forces, which reflected the lack of capacity or integrity (or both) of local police (Shirk and
} 
Military operations are costly, and indeed the government increased the Defense Department's budget over real GDP from $0.24 \%$ in 2006 to $0.47 \%$ by 2012 . If we consider total military expenditure as a percentage of GDP, then it rose from 0.4 to $0.6 \%$ between 2006 and 2012, according to World Bank data. Similarly, expenditure increased in all Mexico's military regions, but regions III, IV, V and VI (where the Drug War waged was particularly intense) recorded larger increases in several years, and an increase well above the average for the period (see Figure A1 in the Appendix). In addition, the budget increases for each military region during the period 2003-2013 is also included in Figures A2a and A2b in the Appendix.

Calderón's determination to fight the drug cartels won the support of the U.S. government. On 30 June 2008, the Merida Initiative was passed by the U.S. congress. As a result of this initiative, the U.S. government offered to support the Mexican government with a threeyear, $\$ 1.4$ billion U.S. Dollar aid package to be used for judicial reform, institution-building, human rights and rule-of-law issues (Shirk 2010). In addition, the Mexican military acquired helicopters and surveillance aircrafts. Despite Calderón's policy (or, perhaps, because of it), the number of homicides in the country rose markedly during the administration. In fact, all criminal activities related to DTOs experienced a significant increase: drug trafficking, homicides, kidnappings, the armed robbery of vehicles, etc.

Figure 2 shows the evolution in military spending and the homicide rate per 100,000 habitants, while Figure 3 displays the evolution of all crimes and the evolution of crimes that are

\footnotetext{
Wallman, 2015). The role played by the navy is particularly interesting; according to Camp (2010), the navy tends to be more transparent than the army, and more willing to cooperate internationally. If we compare the respective forces, we find that in 2012 the navy numbered 53,505 sailors, while the army totaled 209,716 soldiers.
} 
associated with DTOs. The correlation between all crimes and DTO crimes is 0.872 for the period 2003 to 2013 and 0.826 for the period 2007-2013.

\section{(Insert FIGURE 2 around here)}

\section{(Insert FIGURE 3 around here)}

Furthermore, Figure 4 shows that different crimes increased substantially during the period 2006-2012. The largest increases were recorded in extortion (113\%), kidnapping (79\%), homicides $(70 \%)$, and aggravated robbery (41\%). Although a few of these crimes do not follow the same pattern as the other crimes, it is possible that particularly those crimes are undercounted or unreported by authorities.

\section{(Insert FIGURE 4 around here)}

\section{Empirical Strategy}

We use a simple Cobb-Douglas production function, in line with that proposed in Mankiw et al. (1992), and adapt it to the regional $\beta$-convergence hypothesis, as discussed in Barro et al. (1991). $\beta$-convergence refers to the negative relationship between the rate of growth of a particular variable (here GDP per capita) and the initial level of that variable. Furthermore, we model violence and the efforts to fight this violence by introducing a deterrent variable. The development of the theoretical model is presented in Appendix A and B. For our empirical strategy, we introduce the following econometric specification of the dynamic panel data model used herein:

$$
\begin{aligned}
y_{i t}=\alpha & +\left(1+\beta_{1}\right) y_{i t-1}+\beta_{2} k_{i t}+\beta_{3} h_{i t}+\beta_{3} n_{i t}+\delta_{1} \text { Fin. Crisis }_{t} \\
& +\delta_{2} H R_{i t}+\delta_{3} M B_{i t}+\varepsilon_{i t}
\end{aligned}
$$


where $y_{i t}$ is the logarithm of real state GDP in per capita terms, $\alpha$ is the intercept, $y_{i t-1}$ is the logarithm of initial state GDP per capita and $\beta_{1}=-\left(1-e^{-\beta_{0} T}\right)$, which informs us about the speed of convergence. This becomes evident if we transform equation (1) into first differences, as proposed by Arellano and Bond (1991), to eliminate state-specific effects:

$$
\begin{aligned}
y_{i t}-y_{i t-1} & =\alpha-\left(1-e^{-\beta_{0} T}\right) y_{i t-1}+\beta_{2} \Delta k_{i t}+\beta_{3} \Delta h_{i t}+\beta_{3} \Delta n_{i t}+ \\
& +\delta_{1} \Delta \text { Fin. } \text { Crisis }_{t}+\delta_{2} \Delta H R_{i t}+\delta_{3} \Delta M B_{i t}+\Delta \varepsilon_{i t}
\end{aligned}
$$

In this specification, real state GDP is expressed in per capita terms. In addition to fitting the theoretical model, the per capita adjustment of real GDP helps to control for population size and migration. This variable selection is in line with that employed in similar studies, including Abadie and Gardeazabal (2003), Bilgel and Karahasan (2015) and Pinotti (2014).

Furthermore, $k_{i t}$ and $h_{i t}$ are the variables that approximate physical and human capital (in logarithms), respectively, and $n_{i t}$ is the population growth rate. We also introduce a dummy for the 2008-2009 financial crisis, the logarithm of the homicide rate per 100,000 inhabitants $\left(H R_{i t}\right)$, and the logarithm of the approximation of state military spending (army only) in per capita terms $\left(M B_{i t}\right)$. Finally, $\varepsilon_{i t}$ is a stochastic error term.

To ensure that our model is correctly specified, we ran several diagnostic tests to check that no important assumptions of our spatial model are violated. With variance inflection factors between 1.02 and 1.19 for all variables, we can rule out the presence of multicollinearity. To control for heteroscedasticity, we used robust standard errors. Furthermore, we included a oneperiod time lag of the dependent variable to account for the time autocorrelation.

Overall, we expect positive signs for the lagged absolute value of real GDP per capita, physical capital and human capital, whereas the 2008-2009 financial crisis should have a negative impact on the economy of the states. We also expect the homicide rate, as well as the 
other crimes related to DTOs, to negatively affect the economy. In the case of the government's military expenditure variable in the form of army spending, we expect a positive sign, given that the Drug War does not destroy physical assets and that government spending enters the GDP equation positively from the demand side.

\section{Data}

For our estimations, we draw on balanced panel data for all 32 Mexican states (the Distrito Federal, the capital, is considered a contiguous state) for the period 2003-2013. The state-level is the smallest spatial unit for which all the variables considered here were available. During this period, a political change took place at the presidential level. With this, an important shift was recorded in homeland security policy. This period also coincides with the 2007-2012 Directive for the Integral Fight against Drug Trafficking, or 'Drug War'.

We obtained population data for each state from the National Population Council (CONAPO), the institution responsible for overseeing the national census. The last census was conducted in 2015 and the yearly population data reported for each state considers national and international migration. These population data are used to compute per capita figures and violence rates. The time series for real state GDP by state were obtained from INEGI. Figure A3 in the Appendix shows cross-sectional maps of GDP per capita growth from 2004-2013.

In the absence of official capital stock data, we use the figures presented in German-Soto (2015), which are a computation of the capital stock data described in German-Soto (2008). Data for human capital are also scarce. The regional science literature circumvents this problem by using the regional share of population with tertiary education. However, this information is not 
available for the whole period. Therefore, we opted to use state averages of years of schooling instead.

Both INEGI and the Interior Department publish homicide statistics. INEGI uses administrative registers from the National Health Information System (SINAIS), which follow the classification recommended by the WHO, whereas the Interior Department compiles its data from police investigation files. Although INEGI is unable to identify a homicide as being related to a drug crime, we opted for this source for several reasons. First, INEGI is a more trustworthy source than the Interior Ministry due to its autonomy (working as it does independently of any law-enforcement agency). Second, there have been newspaper reports about police forces failing to investigate murders in some northern states due to the great volume of homicides. According to Shirk and Wallman (2015), less than 25 percent of crimes are reported, and only 20 percent of these are investigated. And, third, it has been suggested that the government might manipulate data to improve its approval ratings and to support its security strategy. We obtained other crime data (kidnapping, extortion, car robbery, aggravated robbery, property crimes and fraud) from Mexico's Technical Secretary for the National Security Council (SESNSP), which is part of the Interior Department. The SESNSP gathers crime statistics from the each state attorney's office, and it is, to the best of our knowledge, the best available source for crime data in Mexico.

Information about military and navy budgets is not publicly available at the state level. We undertook searches of government records and budgets but were unable to find state budgets for either military or navy spending. We followed this up with a formal information request, but were informed that this information was only available at the regional level. We managed to obtain regional military budgets for the 12 regions that are made available in the Federation's Expenditure Budget (Presupuesto de Egresos de la Federación, PEF) for each year. This 
subdivision into regions was only available for the military, but not for the navy or federal police. For that reason, we focus on the military budget only.

The budget contains information on a wide range of subjects including the funding destined to each of the 12 military regions. Each region can comprise up to five states. Figure 5 describes which states make up each military region.

\section{(Insert FIGURE 5 around here)}

Due to the lack of data on military budgets by state, we approximate them by allocating the regional budget based on variables that are good indicators of military involvement in the 'Drug War'. First, we summed up the total number of people detained during operations targeting DTO activities and then we calculated the percentage corresponding to each state belonging to same military region. Using these percentages, we assigned the proportional share of the military budget to each state. Moreover, when conducting the robustness checks, we also considered the number of vehicles seized either in operations targeting drug criminals or when conducting searches at specific check-points, and the number of investigation files opened.

Dell (2015) reported that local governments with representatives from the National Action Party (PAN) are more likely to ask for help from the federal government (also PAN at the time). Based on this, we consider a fourth allocation option and allocate regional military budget based on the number of PAN voters at the last governor election.

Using these variables only (and not crime variables) to allocate military budgets adheres to the intuition that military budgets are assigned to those areas (states) where government activity to apprehend DTOs is most intense. Most military regions comprise either two or three states, which means the error associated with the allocation of the budget is limited. Dividing a national budget by the 32 states would, on the other hand, contain a large error. 
The variables selected for the allocation of the regional military budgets during the period considered are well suited because: a) they show temporal and spatial variation, and b) they are closely related to the Drug War strategy initiated by Calderón. For example, if a region comprises two states, one in which DTOs are highly active and one with little DTO activity, we can expect a higher share of the budget during the Drug War to be allocated to the state in which DTOs are more active. All these variables are reported by INEGI in its Anuario Estadístico y Geográfico por Entidad Federativa and are computed specifically for the 'Drug War'. However, they do not refer solely to the actions taken by the military, and include also the efforts of the navy as well as those of the federal and local police. To show some of the characteristics of the variables used for the allocation of military budgets, we report their descriptive statistics in Table A1 in the Appendix.

Table 1 describes the variables used in our econometric specification of the model. Table 2 presents the descriptive statistics for these variables. The rates of kidnapping, extortion, property crimes and fraud include fewer observations because some states did not report occurrences in some years.

\section{(Insert TABLE 1 around here)}

(Insert TABLE 2 around here)

\section{Results}

The results of our policy analysis of the 'Mexican Drug War' are reported in Table 3. Here, various econometric specifications are presented: first, to generate some intuition about the variables, we introduce a restricted version of the model using a fixed effects estimation (columns 1-4). This specification is common for regions for which physical capital and human 
capital variables are unavailable. Then, we refine the accuracy of our estimates by introducing physical and human capital stocks (columns 2-4). In column 2, we introduce the homicide rate provided by INEGI as a proxy for violence and in column 3, we use the military budget allocated by the number of detained people. Column 4 includes both these variables.

\section{(Insert TABLE 3 around here)}

As mentioned, equations 1-4 are estimated with fixed effects so as to generate some intuition. However, fixed effects regressions are biased because they do not account for the dynamic nature of the model. Neglecting to do so leads to consistency issues as described in detail by Nickell (1981). To overcome this, we use the difference-GMM panel data specification developed by Arellano and Bond (1991) in columns 5-8. This method takes into account the dynamic nature of the lagged dependent variable, by differentiating with one-period lagged values correcting for the bias. Because of this, the estimation reports 288 observations instead of 320.

From the performance statistics provided at the bottom of Table 3, we can see that the GMM estimations fit the model well because the $\mathrm{Chi}^{2}$-statistic of the Wald test strongly rejects (at the $1 \%$ level) the null hypothesis of the joint statistical insignificance of the covariates. Due to the inclusion of the lagged value of the dependent variable as a covariate (which is highly significant in the fixed effects estimations), first-order serial correlation in the first-differenced errors is expected. We then reject the existence of second-order serial correlation in the firstdifferenced errors. With these results for the different tests we can affirm that our model is correctly specified and that the moment conditions are valid. 
Difference-GMM panel data estimations rely on a series of lagged variables that are then differenced and used as instruments ${ }^{4}$. The Hansen test checks that the over-identifying restrictions are valid. The inclusion of all possible instruments in a small sample size would result in too many over-identifying restrictions and consequently the specification would perform poorly. To overcome this, and following Roodman (2009a), we restrict the number of instruments in each equation so that the null hypothesis of Hansen's over-identification test (instruments are valid) cannot be rejected.

In all our estimations, we use the same dependent variable: i.e. the logarithm of real state GDP per capita. The logarithm of the lagged value of GDP per capita (interpreted as the initial level) is positive and highly significant for all specifications. Bearing in mind that $\beta_{1}=-(1-$ $e^{-\beta_{0} T}$ ), the results are intuitive and in line with economic theory. Richer economies tend to have lower GDP growth rates while poorer economies tend to have higher rates.

The variable for the per capita physical capital stock performs well, being positive and highly significant. For the human capital variable proxied by average schooling years, the coefficient is positive but in some cases not significant. Such results for human capital, nonsignificant and even sometimes negative, are found in other studies that undertake panel data analyses in an augmented Solow Model framework (Benhabib and Spiegel 1994; Islam 1995). This aspect is often attributed to a lack of variability in the education averages once jurisdictionspecific heterogeneity (state-specific fixed effects) is accounted for.

\footnotetext{
${ }^{4}$ As suggested in Roodman (2009b), all regressors are included into the instrument matrix. The dependent variable, physical capital, human capital, the military budget and the different crime rates are all treated as endogenous, while the rest of the variables are treated as exogenous.
} 
The 2008-2009 financial crisis had a marked impact on Mexican states. As expected, the estimates are negative and highly significant for all specifications. The descriptive map (Figure A3 in the Appendix) shows that in 2008 signs of the crisis began to emerge, but it was not until 2009 that all 32 states reported negative growth rates in their per capita output. Hence, the magnitude and the negative sign of the coefficient of this two-year dummy seems reasonable.

In the approach reported here, we measure growth in the homicide rate, i.e., we focus on the flow but not on the stock of homicides. We obtain negative and highly significant coefficients. A negative sign is clearly intuitive if we consider the wave of violence affecting Mexico to be a deterrent to the states' economic performance. Thus, not only do drug-related homicides seem to affect state economic growth, but the increase in violence in terms of homicides seems to have negative and highly significant marginal effects.

Our results for this DTO-associated crime variable are in line with results in Enamorado et al. (2014) for the drug-related homicide rate (measured in levels). The coefficients indicate a negative association with state GDP per capita. In Pan et al. (2012), the aggregate crime variable has a positive and significant sign, resulting from the fact that their variable is an aggregation of crimes which may have opposite signs.

Here, the military budget allocated based on the number of detained people in each state is positive and highly significant for the full model specification reported in column 8 . In keeping with our claim that the approximated military budget should be a good indicator of where the Drug War strategy was implemented most intensely, this positive association indicates that military spending had a positive effect on state GDP per capita growth.

To address potential issues of reverse causation, we check for the possibility that states with high growth rates demand or receive greater military intervention. To do this, we focus on 
the correlations of our variables (Table A2 in the Appendix) and the auxiliary difference-GMM regression between the growth rate of state GDP per capita and the military budget options. From this analysis, we find that the correlations are minimal while the regression indicates no significant effects. The results of this auxiliary regression can be found in Table A3 in the Appendix.

\section{Allocation Alternatives for Military Expenditure}

Military expenditure is our main variable of interest. For this reason, we consider it both pertinent and necessary to show that the budget is robust to different ways of allocating it. Thus, we tested additional allocation variables associated with the fight waged by the Mexican military against DTOs.

In the category of crimes catalogued as crimes against society, the number of detentions is specifically related to "crimes against health", including such crimes as drug trafficking, terrorist acts, human organ trafficking and trafficking of other illegal products. In addition to the number of people detained during such crimes, INEGI also reports and the number of vehicles seized. Moreover, it is evident that most criminal investigations (per capita) are conducted in those states that are being disputed by DTOs. We chose investigations because it is often the case that the authorities initiate inquiries into shootings between DTOs or they find mass graves in a DTO territory. The results in Table 4 show that the estimates for military expenditure are positive ${ }^{5}$, highly significant, and range from 0.0082 to 0.0202 . Recall that caution is needed

\footnotetext{
${ }^{5}$ Our results for military expenditures present a positive sign that is different from the local expenditure variables reported by Enamorado et al. (2014) and Pan et al. (2012). However, a direct comparison cannot be made because in their models, the public expenditure variables are overly generic, since they target neither the improvement in public
} 
when interpreting the magnitude of this variable, because it is a state approximation for data that are available only at regional level.

\section{(Insert TABLE 4 around here)}

The war waged against DTOs is unlike any other. While typical wars target strategic physical assets such as transport, energy and communication infrastructure, a drug war is waged differently. Ongoing military operations to fight drug criminals bring with them the need for increased government spending, especially to sponsor field operations conducted by military troops (mainly infantry). Thus, rather than facing the widespread destruction of physical assets, the drug war results in increased government expenditure. The extraordinarily high level of military spending by Mexican standards is positively associated with the growth rate of real state per capita GDP. ${ }^{6}$ Mexico presents an annual average increase of $8.33 \%$ between 2006 and 2012 in its real military expenditure, which is much higher than that recorded in the other major countries (population > 20M) of Latin America: Brazil (5.24\%), Colombia (4.92\%), Argentina (2.10\%), Peru (5.87\%) and Venezuela (6.31\%) [Data taken from Stockholm International Peace Research Institute (SIPRI)].

\footnotetext{
security, in general, nor the fight against DTOs, in particular. Moreover, public expenditures in these studies are determined at the local level, while military expenditure is determined at federal level.

6 It is logical to believe that the drug lords will have increased their expenditure on arms, vehicles, personnel (sicarios), and other means to fight increasing government action, thus boosting demand in a state's economy. However, for obvious reasons, we cannot empirically address this assumption.
} 


\section{Robustness of Violence}

To show the robustness of our estimates for the violence variable, we present the estimation results obtained when using alternative proxies for crime and violence. These include rates of kidnapping, extortion, car robbery, aggravated robbery, property crimes and fraud. These criminal activities are often associated with the diversification of DTOs (Rios 2008; Shirk 2012; Calderón et al. 2015). The results are presented in Table 5.

\section{(Insert TABLE 5 around here)}

Comparing the estimates of the violence proxies, we see that all coefficients present a similar magnitude, between -0.00745 and -0.0177 , and are highly significant. In other words, a $100 \%$ increase of the different crime rates would result in a $0.7-1.7$ percentage point decrease of per capita state GDP. The results also show that property crimes, aggravated robbery and homicides have the largest negative effects among the crimes considered here.

Enamorado et al. (2014) calculate that an increase by one standard deviation in the number of drug-related homicides (18 homicides) implies a decrease in growth of 0.20 percentage points. According to our estimates, a one standard deviation increase in the rate of (intentional) homicides per 100,000 inhabitants represents a decrease of 1.21 percentage points in growth. One aspect that might explain this difference is that Enamorado et al. (2014) employ the rate of homicides in 2007 only, which happens to be the same year in which the national homicide rate reached a low point. Hence, our results suggest that the homicide effects reported in Enamorado et al. (2014) would be underestimated.

The results obtained by Pan et al. (2012) show no significant effects associated with homicides. The study also employs an aggregation of crimes for which the authors find positive and significant effects. In order to explore the reason for these positive effects, we conduct an 
additional estimation using crimes not likely to be associated with DTO, e.g. the non-violent theft rate and the manslaughter rate, and find positive but non-significant results ${ }^{7}$. These nonsignificant estimates could give some intuition as to why Pan et al. (2012) find positive results for their aggregated crime variable.

\section{Spatial Effects}

Although most actions undertaken by the states to fight DTOs (i.e. operations conducted by local and state police) are limited by individual state jurisdictions, military action and drug trafficking activities are not. For this reason, we study the existence of spatial effects in neighboring states. Table A4 in the Appendix shows the results of the estimation output for the spatial model. The signs of the coefficients are consistent with those obtained in the difference-GMM model described above. Likewise, the coefficients of the approximated state military spending are positive and in all cases highly significant. Thus, our military budget approximation is robust to the inclusion of a spatial component. Finally, all the crime variables used here are negative and remain significant. ${ }^{8}$

\footnotetext{
${ }^{7}$ Results are available upon request.

${ }^{8}$ The coefficient for the spatial variable (the W-matrix multiplied by the spatially lagged value of state GDP p.c. included in the model) is positive and significant. We perform a standard test to ensure that the spatial coefficient is different from zero. Based on the significance of the values reported in the table, we reject the hypothesis of the spatial coefficient $\rho_{1}$ being equal to 0 .
} 


\section{Conclusion}

This paper has analyzed the Mexican government's policy in its fight against DTOs. Moreover, it has studied the effects of this policy on state GDP per capita using a panel data GMM model developed within the theoretical framework of regional convergence.

We focus our attention on the effects of the policy implemented by the government to fight DTOs as approximated by state-level military spending. As only regional military budgets are available, we propose a state-level approximation of the military budget. We detect two different effects of the 'Drug War' policy on economic growth: on the one hand, the escalation in violence since the adoption of the 'Drug War' strategy has resulted in significant negative effects on economic growth, regardless of the crime variable employed; on the other hand, military expenditure at state level presents a positive and significant effect on state economic growth. Our results indicate that an increase of 100 percentage points in the military budget (allocated using the number of people detained) is associated with an increase of 0.82 to 2.02 points in the state GDP per capita growth rate.

DTOs constitute a serious problem for Mexico, and for other countries on the continent. However, the war waged against these criminal organizations is having several unintended and unforeseen consequences, with particular effects on economic activity. While we have analyzed some of these effects during president Calderón's administration, much more research is needed if we are to gain a better understanding of the problem and of how to address it. To conduct this research, the Mexican authorities need to make more and better data available to researchers, so that different dimensions of this complex public policy problem can be better analyzed. 


\section{References}

Abadie, Alberto and Javier Gardeazabal. 2003. The Economic Costs of Conflict: A Case Study of the Basque Country. American Economic Review 93(1):113-32.

Acemoglu, Daron, James A. Robinson, and Rafael J. Santos. 2013. The Monopoly of Violence: Evidence from Colombia. Journal of the European Economic Association 11(S1):5-44.

Ajzenman, Nicolas, Sebastian Galiani, and Enrique Seira. 2015. On the Distributive Costs of Drug-Related Homicides. Journal of Law and Economics 58(4):779-803.

Alesina, Alberto, Salvatore Piccolo, and Paolo Pinotti. 2016. Organized Crime, Violence, and Politics. NBER Working Paper No. 22093, March 2016.

Andreas, Peter. 2004. Illicit international political economy: the clandestine side of globalization. Review of International Political Economy 11(3):641-52.

Arellano, Manuel and Stephen Bond. 1991. Some tests of specification for panel data: Monte Carlo evidence and an application to employment equations. Review of Economic Studies 58:277-97.

Ashby, Nathan J. and Miguel A. Ramos. 2013. Foreign direct investment and industry response to organized crime: The Mexican case. European Journal of Political Economy 30:80-91.

Astorga, Luis and David A. Shirk. 2010. 'Drug trafficking organizations and counter-drug strategies in the U.S.-Mexican Context', in Eric L. Olson, David A. Shirk and Andrew Selee (eds.) Shared responsibility: U.S.-Mexico policy options for confronting organized crime. Pp. 31-61. Woodrow Wilson International Center for Scholars and Trans-Border Institute, U. C. at San Diego.

Barro, Robert J., Xavier Sala-i-Martin, Olivier J. Blanchard, and Robert E. Hall. 1991. Convergence across States and Regions. Brookings Papers on Economic Activity 1:107-82. 
Benhabib, Jess and Mark M. Spiegel. 1994. The role of human capital in economic development: Evidence from aggregate cross-country data. Journal of Monetary Economics 34:143-73.

Berman, Eli, Jacob N. Shapiro, and Joseph H. Felter. 2011. Can Hearts and Minds Be Bought? The Economics of Counterinsurgency in Iraq. Journal of Political Economy 119(4):766-819.

Bilgel, Firat and Burhan Can Karahasan. 2015. The Economic Costs of Separatist Terrorism in Turkey. Journal of Conflict Resolution, DOI: 0022002715576572.

Cabral, René, André V. Mollick, and Eduardo Saucedo. 2016. Violence in Mexico and its effects on labor productivity. Annals of Regional Science 56(2):317-39.

Cabral, René, André V. Mollick. 2012. Mexico's regional output convergence after NAFTA: a dynamic panel data analysis. The Annals of Regional Science 48:877-95.

Camp, Roderic Ai. 2010. ‘Armed Forces and Drugs: Public Perceptions and Institutional Challenges', in Eric L. Olson, David A. Shirk and Andrew Selee (eds.) Shared responsibility: U.S.-Mexico policy options for confronting organized crime. Woodrow Wilson International Center for Scholars and Trans-Border Institute, U.C. at San Diego.

Carrion-i-Silvestre, Josep Lluís, and Vicente German-Soto. 2007. Stochastic Convergence amongst Mexican States. Regional Studies 41(4):531-41.

Chabat, Jorge. 2010. 'La respuesta del gobierno de Felipe Calderón ante el desafío del narcotráfico: entre lo malo y lo peor', [Felipe Calderón's government response to drug traffic challenge: Between bad and worse] in Arturo Alvarado and Mónica Serrano (eds.) Los grandes problemas de México XV: Seguridad nacional y seguridad interior [Main problems of Mexico XV: National security and homeland security]. Mexico: El Colegio de México.

Chiquiar, Daniel. 2005. Why Mexico's regional income convergence broke down. Journal of Development Economics 77:257-75. 
Dell, Melissa. 2015. Trafficking Networks and the Mexican Drug War. American Economic Review 105(6):1738-79.

Department of Justice. 2010. National Drug Threat Assessment 2010, Johnstown, PA. Available online at the United States Department of Justice Archives.

Enamorado, Ted, Luis F. López-Calva, and Carlos Rodríguez-Castelán. 2014. Crime and growth convergence: evidence from Mexico. Economics Letters 125(1):9-13.

Enamorado, Ted, Luis F. López-Calva, Carlos Rodríguez-Castelán, and Hernán Winkler. 2016. Income inequality and violent crime: Evidence from Mexico's drug war. Journal of Development Economics 120:128-43.

Fernández-Menéndez, Jorge, and Víctor Ronquillo. 2006. De los Maras a los Zetas. Los secretos del narcotráfico, de Colombia a Chicago [From Maras to Zetas. The drug trafficking’s secrets, from Colombia to Chicago]. Mexico: Grijalbo Mondadori.

Germán-Soto, Vicente. 2008. El stock de capital industrial medido a través de la relación inversión-empleo: estimaciones para los estados mexicanos, [The stock of industrial capital measured through the investment-employment relationship: estimates for the Mexican states]. Ensayos 27(1):53-80.

Germán-Soto, Vicente. 2015. Capital Stock Series of the Mexican Regions. Accessed April 2017. Available at http://works.bepress.com/vicente_german_soto/30/

Islam, Nazrul. 1995. Growth Empirics: A Panel Data Approach. Quarterly Journal of Economics 110(4):1127-70

Levitt, Steven and Sudhir Alladi Venkatesh. 2000. An Economic Analysis of a Drug-Selling Gang's Finances. Quarterly Journal of Economics 115(3):755-89. 
Mankiw, N. Gregory, David Romer, and David N. Weil. 1992. A contribution to the empirics of economic growth. Quarterly Journal of Economics 107(2):407-37.

Márquez-Padilla, Fernanda, Francisco Pérez-Arce, and Carlos Rodríguez-Castelán. 2015. The (non-) effect of violence on education: evidence from the "war on drugs" in Mexico. Policy Research Working Paper 7230, The World Bank.

McDonald, James H. 2005. The Narcoeconomy and Small-Town, Rural Mexico. Human Organization 64(2):115-25.

Nickell, Stephen. 1981. Biases in Dynamic Models with Fixed Effects. Econometrica 49(6):1417-26.

Norwegian Refugee Council/Internal Displacement Monitoring Centre (NRC/IDMC), 2010. Briefing paper by the Norwegian Refugee Council's Internal Displacement Monitoring Centre on forced displacement in Mexico due to drug cartel violence. December 2010; Accessed April 2017. Available at http://www.refworld.org/docid/4d2714522.html.

Orozco-Alemán, Sandra, and Heriberto González-Lozano. 2017. Drug Violence and Migration Flows: Lessons from the Mexican Drug War. Journal of Human Resources, Published online, doi: 10.3368/jhr.53.3.0215-6948R4.

Pan, Mingming, Benjamin Widner, and Carl E. Enomoto. 2012. Growth and Crime in Contiguous States in Mexico. Review of Urban and Regional Development Studies 24(1):5164.

Pinotti, Paolo. 2015. The Economic Costs of Organised Crime: Evidence from Southern Italy. Economic Journal 125(586):F203-32. 
Rasmussen, David W., Bruce L. Benson, and David L. Sollars. 1993. Spatial Competition in Illicit Drug Markets: The Consequences of Increased Drug Law Enforcement. Review of Regional Studies 23(3):219-36.

Rios, Viridiana. 2008. Evaluating the Economic Impact of Mexico's Drug Trafficking Industry. Unpublished manuscript, Harvard University, Department of Government.

Rios, Viridiana. 2013. Why did Mexico become so violent? Trends in Organized Crime $16(2): 138-55$.

Robles, Gustavo, Gabriela Calderón, and Beatriz Magaloni. 2013. Economic Consequences of Drug-Trafficking Violence in Mexico. IDB working paper series \# IDB-WP-426.

Rodríguez-Oreggia, Eduardo. 2005. Regional disparities and determinants of growth in Mexico. The Annals of Regional Science 39:207-20.

Roodman, David. 2009a. A note on the theme of too many instruments. Oxford Bulletin of Economics and Statistics 71(1):135-58.

Roodman, David. 2009b. How to do xtabond2: An introduction to difference and system GMM in Stata. The Stata Journal 9(1):86-136.

Shirk, David A. 2010. Drug Violence in Mexico - Data and Analysis from 2001-2009. TransBorder Institute, U.C. at San Diego.

Shirk, David A. 2012. Drug Violence and State Responses in Mexico. Unpublished manuscript, U.C. at San Diego, Department of Political Science.

Shirk, David A. and Joel Wallman. 2015. Understanding Mexico’s Drug Violence. Journal of Conflict Resolution 59(8):1348-76. 
Snyder, Richard and Angelica Duran-Martinez. 2009. Does illegality breed violence? Drug trafficking and state-sponsored protection rackets. Crime, Law, and Social Change 52(3):25373.

United States Congress, Joint Economic Committee (2002) The Economic costs of terrorism. Available at the United States Homeland Security Digital Library.

Williams, Phil. 2012. The Terrorism Debate over Mexican Drug Trafficking Violence. Terrorism and Political Violence 24(2):259-78.

Zapata, B. 2011. Gobiernos extranjeros hacen recomendaciones por inseguridad en México [Foreign governments make recommendations due to insecurity in Mexico], Expansión, 9 February; Accessed April 2017. Available at http://expansion.mx/nacional/2011/02/09/gobiernos-extranjeros-hacen-recomendaciones-porinseguridad-en-mexico 


\section{TABLES}

Table 1: Description of Variables

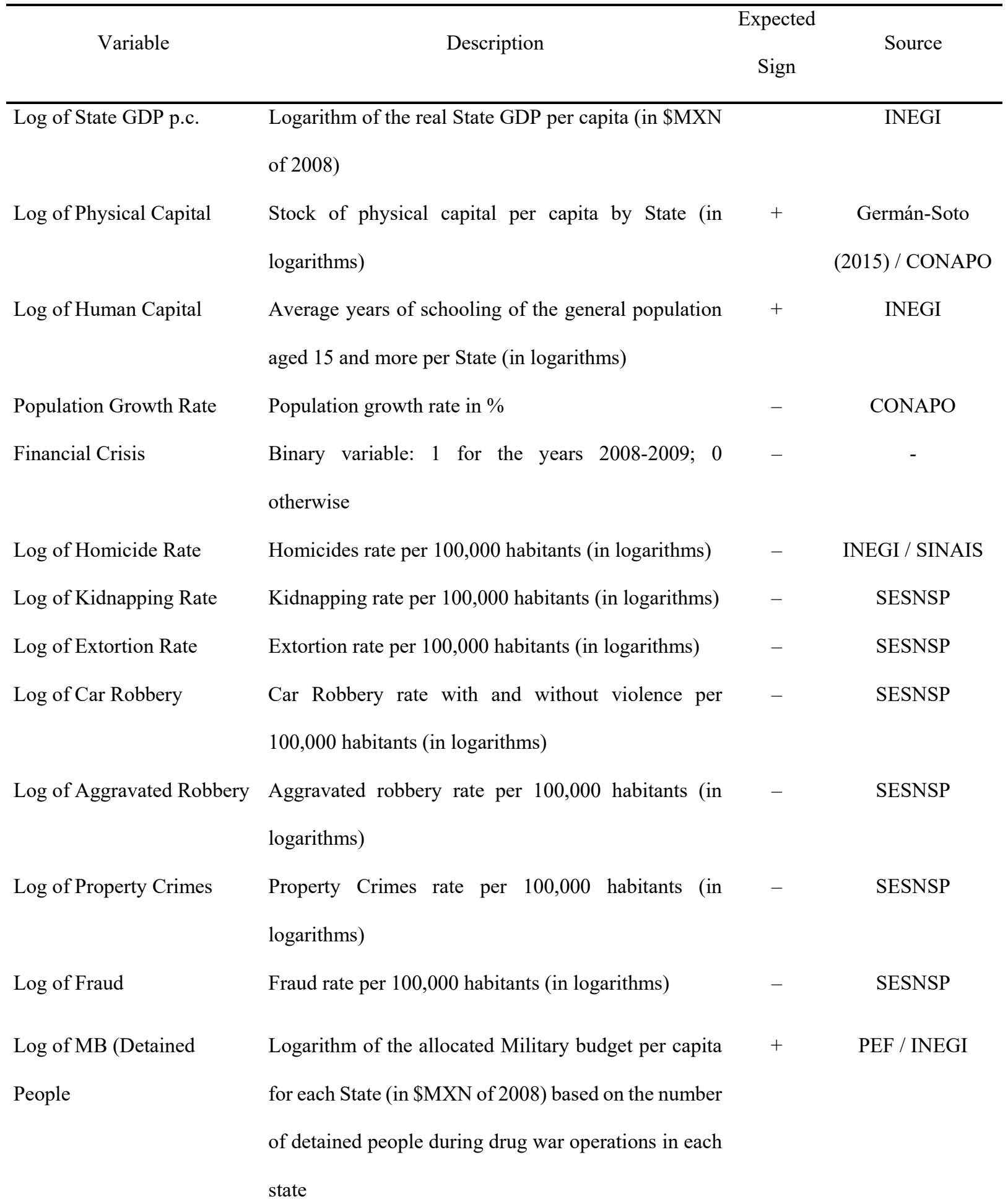


Log of MB (Seized

Vehicles)

Log of MB (Investigations)
Logarithm of the allocated Military budget per capita for each State (in \$MXN of 2008) based on the number of seized vehicles during drug war operations

Logarithm of the allocated Military budget per capita for each State (in \$MXN of 2008) based on the number of investigations opened in each state

\author{
Log of MB (PAN Voters)
}

$+$

$\mathrm{PEF} / \mathrm{INEGI}$

PEF / INEGI

Logarithm of the allocated Military budget per capita

$+$

PEF / INEGI for each State (in \$MXN of 2008) based on the number of PAN voters during the last governor election 
Table 2: Descriptive Statistics of the Model

\begin{tabular}{|c|c|c|c|c|c|}
\hline Variable & Mean & $\begin{array}{c}\text { Std. } \\
\text { Deviation }\end{array}$ & Min. & Max. & Obs. \\
\hline Log of GDP p.c. & 11.4737 & 0.5723 & 10.5101 & 13.9922 & 320 \\
\hline Log of Physical Capital & -2.9863 & 0.8156 & -4.6369 & -0.6614 & 320 \\
\hline Log of Human Capital & 2.1253 & 0.1110 & 1.7846 & 2.3780 & 320 \\
\hline Population Growth Rate & 0.0145 & 0.0072 & -0.0020 & 0.0388 & 320 \\
\hline Financial Crisis & 0.2000 & 0.4006 & 0.0000 & 1.0000 & 320 \\
\hline Log of Homicide Rate & 2.3315 & 0.8578 & 0.5403 & 5.2048 & 320 \\
\hline Log of Kidnapping Rate & -0.6922 & 1.1867 & -3.9120 & 3.6014 & 284 \\
\hline Log of Extortion Rate & 1.2401 & 1.0675 & -2.9957 & 3.5888 & 263 \\
\hline Log of Car Robbery & 4.4647 & 1.0642 & 0.7696 & 7.0108 & 320 \\
\hline Log of Aggravated Robbery & 4.4099 & 1.0635 & 0.0091 & 7.1547 & 320 \\
\hline Log of Property Crimes & 5.2891 & 0.7036 & 2.4360 & 6.5503 & 319 \\
\hline Log of Fraud & 3.8444 & 0.8208 & -1.4819 & 5.021314 & 318 \\
\hline Log of MB (Detained People) & 19.6575 & 1.2211 & 15.8109 & 23.3908 & 320 \\
\hline Log of MB (Seized Vehicles) & 19.7143 & 1.2000 & 16.1260 & 23.1624 & 320 \\
\hline Log of MB (Investigations) & 19.6900 & 1.1514 & 17.1934 & 23.4032 & 320 \\
\hline Log of MB (PAN Voters) & 19.6967 & 1.2729 & 16.0736 & 23.1586 & 320 \\
\hline
\end{tabular}


Table 3: Estimation Results of the Fixed Effects and Difference GMM Models

\begin{tabular}{|c|c|c|c|c|c|c|c|c|}
\hline $\begin{array}{c}\text { Dep. Variable: } \\
\text { Log of State GDP p.c. }\end{array}$ & $\begin{array}{c}\text { (1) } \\
\text { Fixed } \\
\text { Effects }\end{array}$ & $\begin{array}{c}(2) \\
\text { Fixed } \\
\text { Effects }\end{array}$ & $\begin{array}{c}\text { (3) } \\
\text { Fixed } \\
\text { Effects }\end{array}$ & $\begin{array}{c}(4) \\
\text { Fixed } \\
\text { Effects }\end{array}$ & $\begin{array}{c}(5) \\
\text { Difference } \\
\text { GMM }\end{array}$ & $\begin{array}{c}(6) \\
\text { Difference } \\
\text { GMM }\end{array}$ & $\begin{array}{c}(7) \\
\text { Difference } \\
\text { GMM }\end{array}$ & $\begin{array}{c}(8) \\
\text { Difference } \\
\text { GMM }\end{array}$ \\
\hline Log of State GDP p.c. (t-1) & $\begin{array}{l}0.814 * * * \\
(0.0317)\end{array}$ & $\begin{array}{l}0.616 * * * \\
(0.0357)\end{array}$ & $\begin{array}{l}0.615 * * * \\
(0.0357)\end{array}$ & $\begin{array}{l}0.613 * * * \\
(0.0357)\end{array}$ & $\begin{array}{c}0.633 * * * \\
(0.109)\end{array}$ & $\begin{array}{l}0.361 * * * \\
(0.0221)\end{array}$ & $\begin{array}{l}0.373 * * * \\
(0.0403)\end{array}$ & $\begin{array}{l}0.347 * * * \\
(0.0352)\end{array}$ \\
\hline Log of Physical Capital & & $\begin{array}{l}0.215 * * * \\
(0.0229)\end{array}$ & $\begin{array}{l}0.211 * * * \\
(0.0230)\end{array}$ & $\begin{array}{l}0.212 * * * \\
(0.0230)\end{array}$ & & $\begin{array}{l}0.540 * * * \\
(0.0207)\end{array}$ & $\begin{array}{l}0.550 * * * \\
(0.0394)\end{array}$ & $\begin{array}{l}0.489 * * * \\
(0.0259)\end{array}$ \\
\hline Log of Human Capital & & $\begin{array}{l}0.136^{* *} \\
(0.0616)\end{array}$ & $\begin{array}{c}0.0614 \\
(0.0666)\end{array}$ & $\begin{array}{c}0.0945 \\
(0.0721)\end{array}$ & & $\begin{array}{l}0.251 * * * \\
(0.0276)\end{array}$ & $\begin{array}{l}0.122 * * \\
(0.0604)\end{array}$ & $\begin{array}{c}0.0832 \\
(0.0753)\end{array}$ \\
\hline Financial Crisis & $\begin{array}{c}-0.0505 * * * \\
(0.00458)\end{array}$ & $\begin{array}{l}-0.0375 * * * \\
(0.00426)\end{array}$ & $\begin{array}{l}-0.0379 * * * \\
(0.00423)\end{array}$ & $\begin{array}{l}-0.0373 * * * \\
(0.00426)\end{array}$ & $\begin{array}{c}-0.0742 * * * \\
(0.0161)\end{array}$ & $\begin{array}{l}-0.0201 * * * \\
(0.00194)\end{array}$ & $\begin{array}{l}-0.0179 * * * \\
(0.00293)\end{array}$ & $\begin{array}{c}-0.0191 * * * \\
(0.00170)\end{array}$ \\
\hline Log of Homicide Rate & $\begin{array}{l}-0.00436 \\
(0.00426)\end{array}$ & $\begin{array}{l}-0.00361 \\
(0.00387)\end{array}$ & & $\begin{array}{l}-0.00475 \\
(0.00400)\end{array}$ & $\begin{array}{l}0.0301 * * * \\
(0.00761)\end{array}$ & $\begin{array}{l}-0.0037 * * * \\
(0.00102)\end{array}$ & & $\begin{array}{c}-0.0141 * * * \\
(0.00253)\end{array}$ \\
\hline Log of MB (Detained People) & $\begin{array}{l}0.00491 * \\
(0.00297)\end{array}$ & & $\begin{array}{c}0.00244 \\
(0.00292)\end{array}$ & $\begin{array}{c}0.00334 \\
(0.00301)\end{array}$ & $\begin{array}{c}-0.0265 * * * \\
(0.00973)\end{array}$ & & $\begin{array}{l}0.0209 * * * \\
(0.00475)\end{array}$ & $\begin{array}{l}0.0202 * * * \\
(0.00272)\end{array}$ \\
\hline Number of Instruments & & & & & 16 & 33 & 27 & 36 \\
\hline $\mathrm{Chi}^{2}$ of the Wald Test & & & & & $340.6 * * *$ & $106,178 * * *$ & $7,561 * * *$ & $18,219 * * *$ \\
\hline $\operatorname{AR}(1)$ & & & & & $-2.302 * *$ & $-2.717 * * *$ & $-2.479 * *$ & $-2.785 * * *$ \\
\hline $\operatorname{AR}(2)$ & & & & & 0.0601 & -0.803 & -0.482 & -0.410 \\
\hline Hansen Test p-value & & & & & 0.384 & 0.474 & 0.199 & 0.525 \\
\hline
\end{tabular}

Note: Dependent variable: Log of State GDP per capita. Constant term not included in the table. MB is the military budget allocated by the rate of detained people. Robust standard errors in parentheses. ${ }^{* * *} \mathrm{p}<0.01,{ }^{* *} \mathrm{p}<0.05, * \mathrm{p}<0.1$. 
Table 4: Estimation Results Using Different Variables to Allocate Military Expenditure

\begin{tabular}{|c|c|c|c|c|}
\hline $\begin{array}{c}\text { Dep. Variable: } \\
\text { Log of State GDP p.c. }\end{array}$ & $\begin{array}{c}(1) \\
\text { Difference } \\
\text { GMM }\end{array}$ & $\begin{array}{c}(2) \\
\text { Difference } \\
\text { GMM }\end{array}$ & $\begin{array}{c}(3) \\
\text { Difference } \\
\text { GMM }\end{array}$ & $\begin{array}{c}(4) \\
\text { Difference } \\
\text { GMM }\end{array}$ \\
\hline Log of State GDP p.c. (t-1) & $\begin{array}{c}0.347 * * * \\
(0.0352)\end{array}$ & $\begin{array}{l}0.391 * * * \\
(0.0227)\end{array}$ & $\begin{array}{l}0.371 * * * \\
(0.0280)\end{array}$ & $\begin{array}{c}0.386^{* * *} \\
(0.0183)\end{array}$ \\
\hline Log of Physical Capital & $\begin{array}{c}0.489 * * * \\
(0.0259)\end{array}$ & $\begin{array}{l}0.488 * * * \\
(0.0234)\end{array}$ & $\begin{array}{c}0.482 * * * \\
(0.0166)\end{array}$ & $\begin{array}{l}0.486 * * * \\
(0.0219)\end{array}$ \\
\hline Log of Human Capital & $\begin{array}{c}0.0832 \\
(0.0753)\end{array}$ & $\begin{array}{c}0.0604 \\
(0.0734)\end{array}$ & $\begin{array}{l}0.0864 * \\
(0.0457)\end{array}$ & $\begin{array}{l}0.100 * * \\
(0.0490)\end{array}$ \\
\hline Population Growth Rate & $\begin{array}{l}-1.178 \\
(1.076)\end{array}$ & $\begin{array}{l}-1.385 \\
(1.281)\end{array}$ & $\begin{array}{l}1.833 * * \\
(0.733)\end{array}$ & $\begin{array}{c}0.767 \\
(0.656)\end{array}$ \\
\hline Financial Crisis & $\begin{array}{l}-0.0191 * * * \\
(0.00170)\end{array}$ & $\begin{array}{c}-0.0212 * * * \\
(0.00198)\end{array}$ & $\begin{array}{c}-0.0246 * * * \\
(0.00223)\end{array}$ & $\begin{array}{c}-0.0226 * * * \\
(0.00229)\end{array}$ \\
\hline Log of Homicide Rate & $\begin{array}{l}-0.0141 * * * \\
(0.00253)\end{array}$ & $\begin{array}{c}-0.00851 * * * \\
(0.00255)\end{array}$ & $\begin{array}{c}-0.00550 * * * \\
(0.00196)\end{array}$ & $\begin{array}{c}-0.00424 * * * \\
(0.00123)\end{array}$ \\
\hline Log of MB (Detained People) & $\begin{array}{l}0.0202 * * * \\
(0.00272)\end{array}$ & & & \\
\hline Log of MB (Seized Vehicles) & & $\begin{array}{l}0.0183 * * * \\
(0.00313)\end{array}$ & & \\
\hline Log of MB (Investigations) & & & $\begin{array}{l}0.0168 * * * \\
(0.00285)\end{array}$ & \\
\hline Log of MB (PAN Voters) & & & & $\begin{array}{c}0.00818 * * * \\
(0.00238)\end{array}$ \\
\hline Observations & 288 & 288 & 288 & 288 \\
\hline Number of States & 32 & 32 & 32 & 32 \\
\hline Number of Instruments & 36 & 36 & 36 & 36 \\
\hline $\operatorname{AR}(1)$ & $-2.785 * * *$ & $-2.862 * * *$ & $-3.055 * * *$ & $-3.173 * * *$ \\
\hline $\operatorname{AR}(2)$ & -0.410 & -0.589 & -0.522 & -0.504 \\
\hline $\mathrm{Chi}^{2}$ of the Wald Test & $18,219 * * *$ & $12,572 * * *$ & $84,799 * * *$ & $156,583 * * *$ \\
\hline Hansen Test $p$-value & 0.525 & 0.542 & 0.516 & 0.531 \\
\hline
\end{tabular}


Table 5: Estimation Results Using Alternative Crime Rates in Mexican States

\begin{tabular}{|c|c|c|c|c|c|c|c|}
\hline & (1) & (2) & (3) & (4) & (5) & (6) & (7) \\
\hline Dep. Variable: & Difference & Difference & Difference & Difference & Difference & Difference & Difference \\
\hline Log of State GDP p.c. & GMM & GMM & GMM & GMM & GMM & GMM & GMM \\
\hline \multirow[t]{2}{*}{ Log of State GDP p.c. (t-1) } & $0.347 * * *$ & $0.205 * * *$ & $0.367 * * *$ & $0.345 * * *$ & $0.400 * * *$ & $0.362 * * *$ & $0.279 * * *$ \\
\hline & $(0.0352)$ & $(0.0263)$ & $(0.0309)$ & $(0.0382)$ & $(0.0227)$ & $(0.0261)$ & $(0.0207)$ \\
\hline \multirow[t]{2}{*}{ Log of Physical Capital } & $0.489 * * *$ & $0.619 * * *$ & $0.552 * * *$ & $0.499 * * *$ & $0.449 * * *$ & $0.527 * * *$ & $0.584 * * *$ \\
\hline & $(0.0259)$ & $(0.0237)$ & $(0.0249)$ & $(0.0308)$ & $(0.0153)$ & $(0.0247)$ & $(0.0229)$ \\
\hline \multirow[t]{2}{*}{ Log of Human Capital } & 0.0832 & $0.267 * * *$ & 0.0360 & $0.119 * *$ & $0.0974 *$ & -0.0223 & -0.0117 \\
\hline & $(0.0753)$ & $(0.0633)$ & $(0.0862)$ & $(0.0530)$ & $(0.0571)$ & $(0.0354)$ & $(0.0573)$ \\
\hline \multirow[t]{2}{*}{ Population Growth Rate } & -1.178 & $1.357 * *$ & 0.799 & 0.668 & $2.340 * * *$ & -1.146 & $-3.216^{* * *}$ \\
\hline & $(1.076)$ & $(0.687)$ & $(1.753)$ & $(0.592)$ & $(0.759)$ & $(1.032)$ & $(0.970)$ \\
\hline \multirow[t]{2}{*}{ Financial Crisis } & $-0.0191 * * *$ & $-0.0119 * * *$ & $-0.0237 * * *$ & $-0.0209 * * *$ & $-0.0292 * * *$ & $-0.0188 * * *$ & $-0.0129 * * *$ \\
\hline & $(0.00170)$ & $(0.00197)$ & $(0.00243)$ & $(0.00244)$ & $(0.00132)$ & $(0.00314)$ & $(0.00238)$ \\
\hline \multirow[t]{2}{*}{ Log of MB (Detained People) } & $0.0202 * * *$ & $0.0165 * * *$ & $0.0158 * * *$ & $0.0131 * * *$ & $0.0170 * * *$ & $0.0122 * * *$ & $0.0178 * * *$ \\
\hline & $(0.00272)$ & $(0.00293)$ & $(0.00548)$ & $(0.00272)$ & $(0.00325)$ & $(0.00270)$ & $(0.00396)$ \\
\hline Log of Homicide Rate & $-0.0141 * * *$ & & & & & & \\
\hline
\end{tabular}

Log of Kidnapping Rate

Log of Extortion Rate

Log of Car Robbery Rate

Log of Aggravated Robbery Rate

Log of Property Crime Rate
$-0.00823 * * *$

(0.000642)

$(0.00347)$

$$
\begin{gathered}
-0.0109 * * * \\
(0.00212)
\end{gathered}
$$

$-0.0148 * * *$

$(0.00362)$

$-0.0177^{* * *}$ 
(0.00218)

Log of Fraud Rate

$-0.00846^{* * *}$

$(0.00127)$

\begin{tabular}{|c|c|c|c|c|c|c|c|}
\hline Observations & 288 & 241 & 230 & 288 & 288 & 286 & 284 \\
\hline Number of States & 32 & 31 & 31 & 32 & 32 & 32 & 32 \\
\hline Number of Instruments & 36 & 33 & 33 & 36 & 36 & 36 & 33 \\
\hline $\mathrm{Chi}^{2}$ of the Wald Test & $18,219 * * *$ & $8,126^{* * *}$ & $41,252 * * *$ & $26,849 * * *$ & $3,320 * * *$ & $58,567 * * *$ & $5,759 * * *$ \\
\hline $\operatorname{AR}(1)$ & $-2.785 * * *$ & -1.603 & $-1.842 *$ & $-3.248 * * *$ & $-3.352 * * *$ & $-2.744 * * *$ & $-2.053 * *$ \\
\hline $\operatorname{AR}(2)$ & -0.410 & -1.056 & 0.308 & -0.252 & 0.654 & -0.678 & -0.991 \\
\hline Hansen Test $p$-value & 0.525 & 0.616 & 0.377 & 0.488 & 0.394 & 0.618 & 0.408 \\
\hline
\end{tabular}

Note: Dependent variable: Log of State GDP per capita. MB is the military budget allocated by the rate of detained people.

Robust standard errors in parentheses. $* * * \mathrm{p}<0.01, * * \mathrm{p}<0.05, * \mathrm{p}<0.1$. 


\section{FIGURE CAPTIONS}

Figure 1: Public Security Expenditure Shares in Mexico, 2003-2013

Figure 2: Evolution of Real Military Spending and Homicides per 100,000 Inhabitants, 20002013

Figure 3: Quarterly Evolution of All Crimes and Crimes Associated with Drug Trafficking Organizations, 2003-2013

Figure 4: Crime Variables Associated with Drug Trafficking Organizations per 100,000 Inhabitants, 1999-2013

Figure 5: Mexican Military Regions

\section{Appendix Figure Captions}

Figure A1: Cumulated Growth Rate of the Real Military Budget for All Military Regions for the Period 2006-2012

Figure A2a: Growth Rate of the Real Military Budget in Military Regions One to Six, 2003-2013 Figure A2b: Growth Rate of the Real Military Budget in Military Regions Seven to Twelve, 2003-2013

Figure A3: Real GDP per Capita Growth Rates, 2004-2013 


\section{FIGURES}

Figure 2

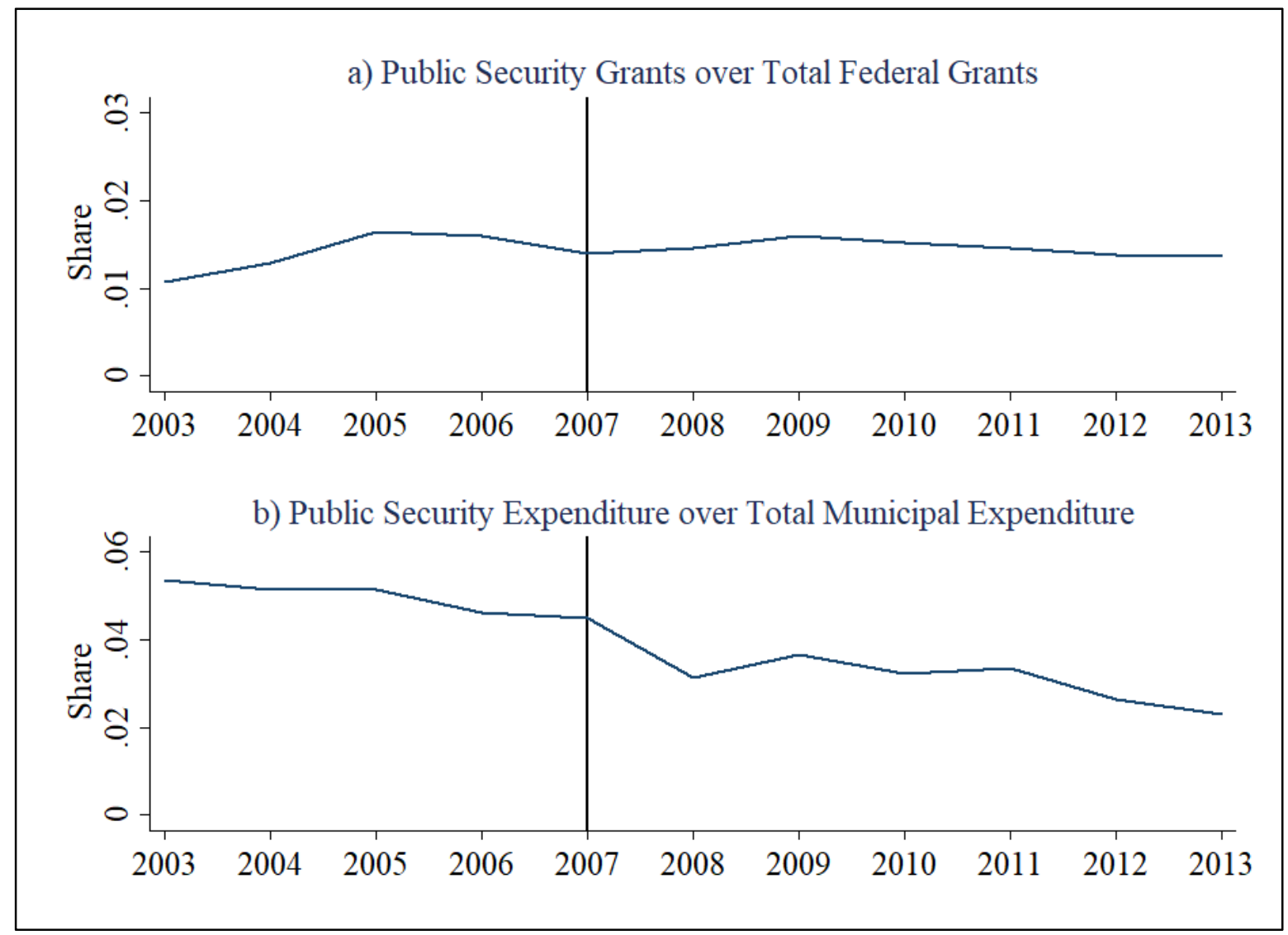

Source: Panel a): based on data from INEGI; Panel b): based on data from the Secretariat of

Finance (SHCP) through the National Federalism and Municipal Development Institute (INAFED). 
Figure 2

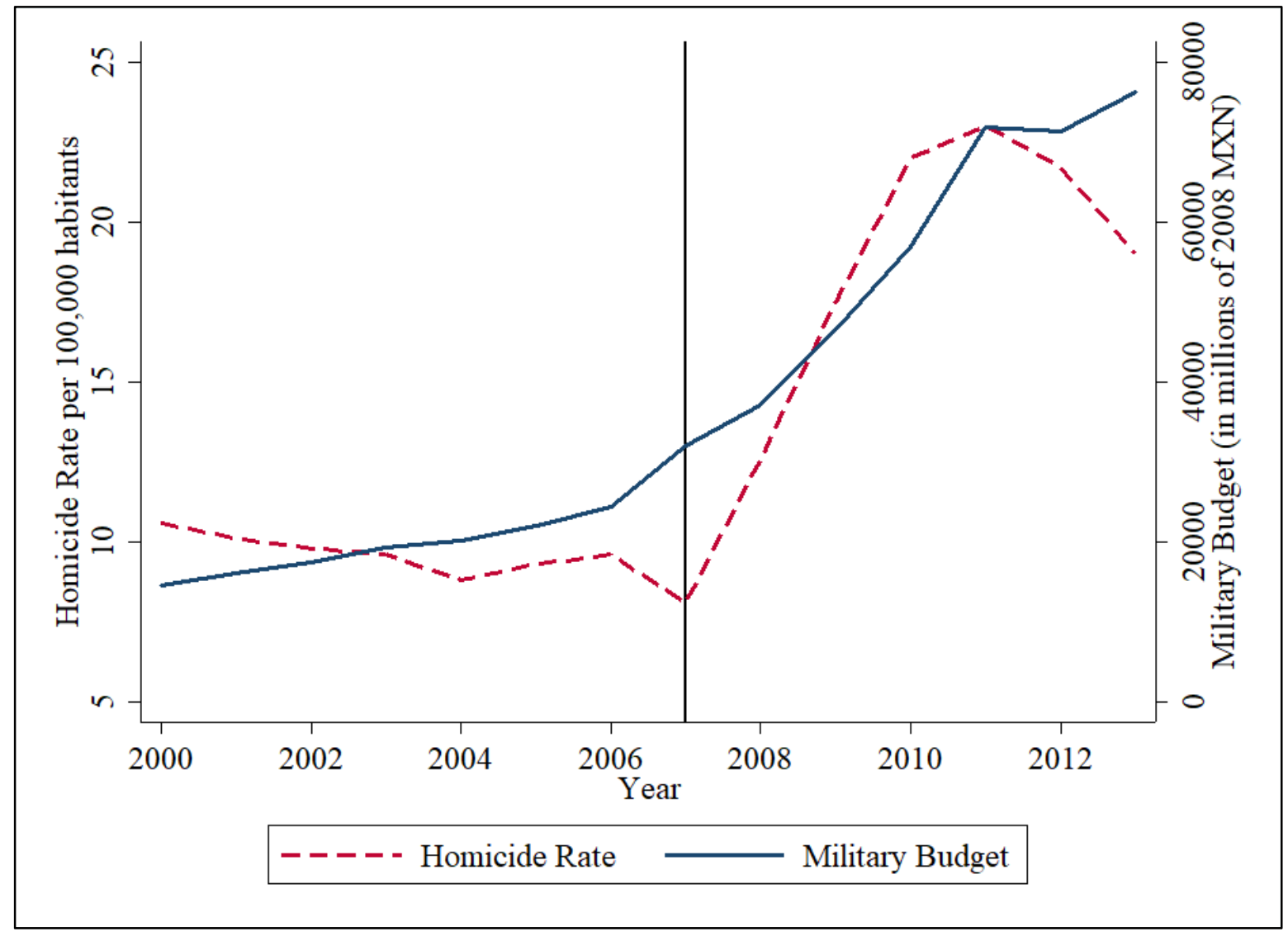

Source: Based on data from INEGI and PEF 
Figure 3

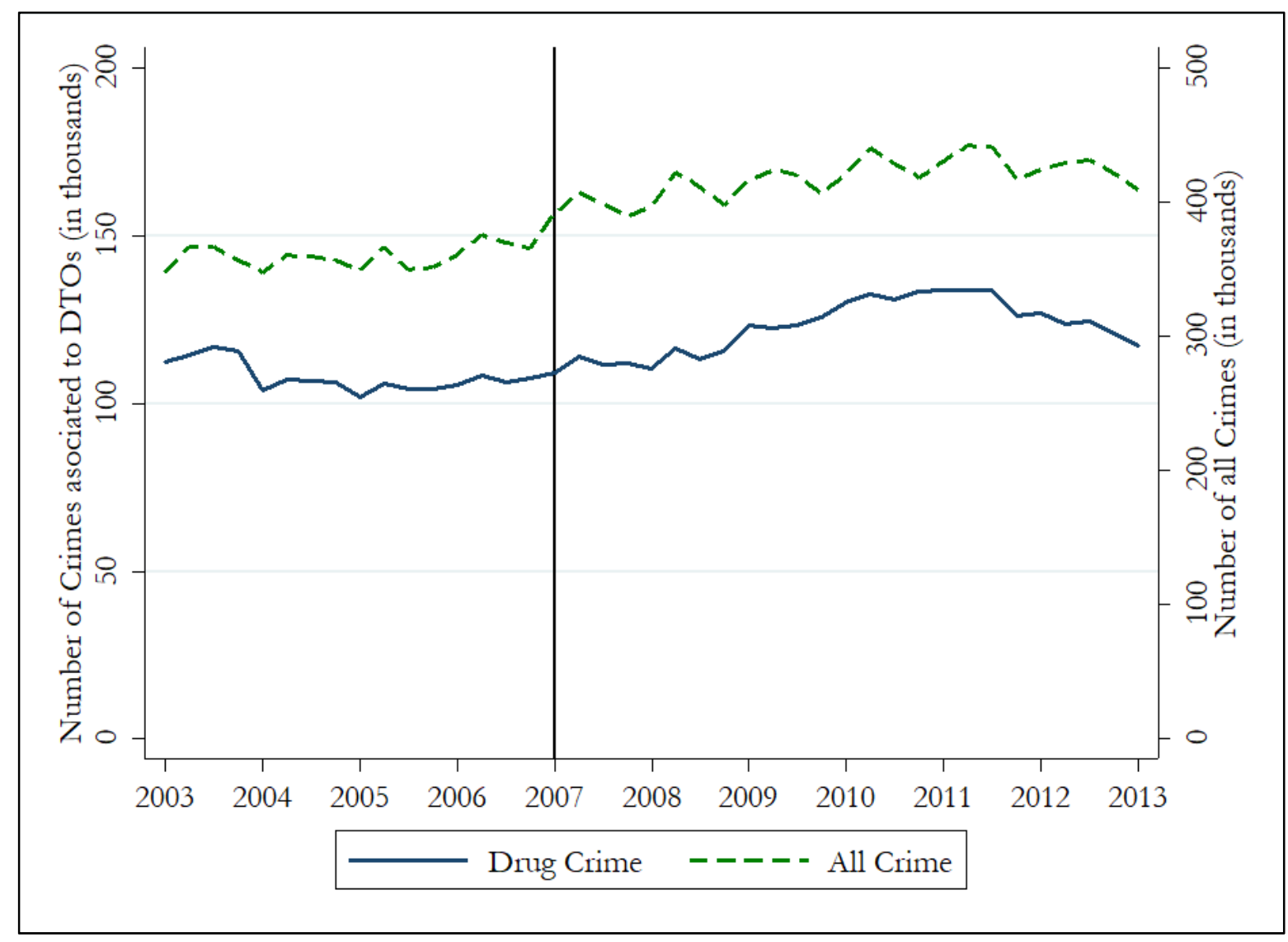

Note: The crimes associated to DTOs are: homicides, kidnapping for ransom, aggravated robbery, extortion and property crimes. Source: Based on data from INEGI and SESNSP. 
Figure 4

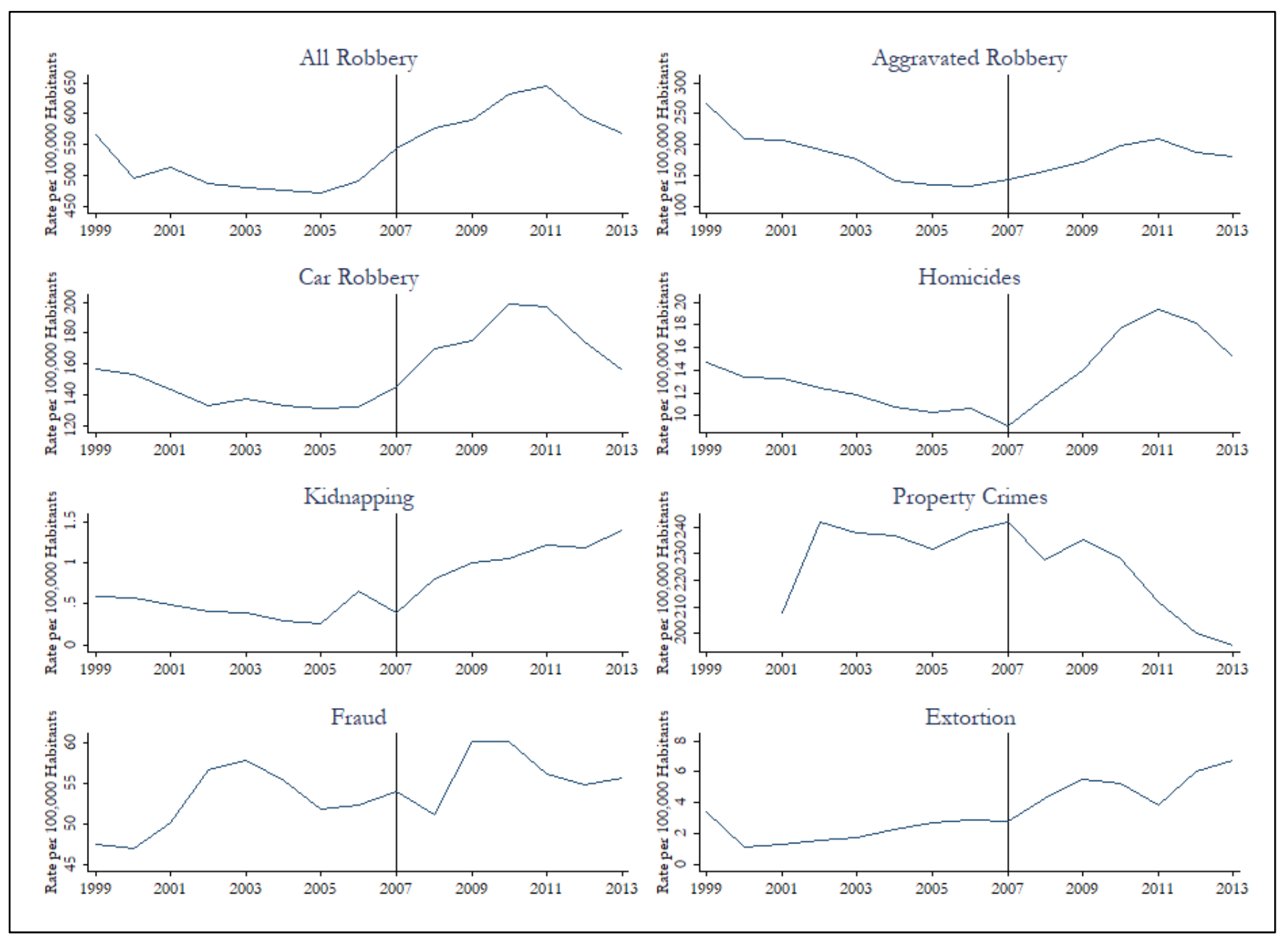

Source: Based on data from INEGI and SESNSP. 
Figure 5

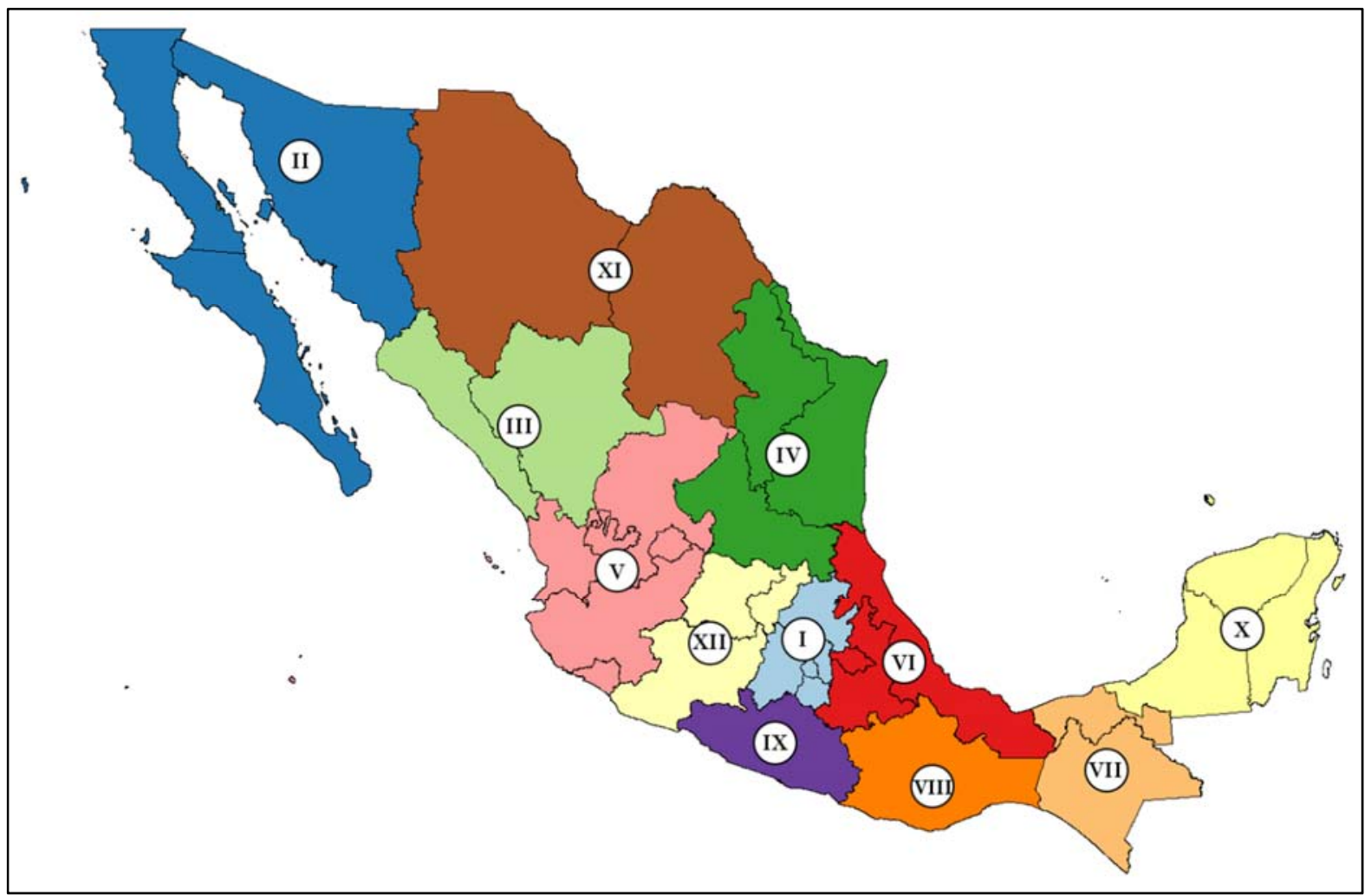

Note: The Mexican Military Regions comprise the following federal states:

Military Region I: $\quad$ Distrito Federal; Hidalgo; State of Mexico; Morelos

Military Region II: Baja California; Baja California Sur; Sonora

Military Region III: Sinaloa; Durango

Military Region IV: Nuevo León; San Luis Potosí; Tamaulipas

Military Region V: Aguascalientes; Colima; Jalisco; Nayarit; Zacatecas

Military Region VI: Puebla; Tlaxcala; Veracruz

Military Region VII: Chiapas; Tabasco

Military Region VIII: Oaxaca

Military Region IX: Guerrero

Military Region X: Campeche; Quintana Roo; Yucatán

Military Region XI: Chihuahua; Coahuila

Military Region XII: Guanajuato; Michoacán; Querétaro 


\section{APPENDIX}

\section{Appendix 1. Theoretical Framework}

We work with a regional economy growth model, where in region $i$ during time $t$ the economy uses labor $\left(L_{i t}\right)$, physical $\left(K_{i t}\right)$ and human $\left(H_{i t}\right)$ capital stocks, as well as the state of technology $\left(A_{i t}\right)$ to produce its output $\left(Y_{i t}\right)$. In addition, we introduce an output deterrent variable $\left(Z_{i t}\right)$, which in our context will be a violence function $Z_{i t}=f\left(V_{i t}, S_{i t}\right) \leq 1$, with $V_{i t}$ being the loss due to violence in our economy and $S_{i t}$ is some form of State intervention to fight the levels of violence. If $Z_{i t}=1$, our economy is not affected by violence problems. On the other hand, if $Z_{i t}=0$, our economy will not be able to function properly. The average labor productivity $\left(y_{i t}\right)$ is a function of the average levels of physical and human capital stocks:

$$
y_{i t}=A_{i t} Z_{i t} k_{i t}^{\alpha} h_{i t}^{\beta}
$$

where $\alpha>0$ and $\beta>0$ are the internal rates of return for physical and human capital stocks respectively. We also assume that $\alpha+\beta<1$. Technology is assumed to grow exogenously and equally for all economies. The spillovers of neighboring economies are defined by $\gamma$, which is the spillover intensity. If $\gamma=0$, neighboring economies do not affect our incumbent economy, while if $\gamma=1$, our economy will be affected for good or for worse. When the neighboring economies are bigger than the incumbent is, the influence is likely to be higher. For simplicity, we assume all economies to have the same influence on their neighbors. The factors $k_{\rho i t}$ and $h_{\rho i t}$ are the per capita ratios of physical, and human capital. $Z_{\rho i t}$ denotes the violence function affecting the neighboring economies.

$$
y_{i t}=Z_{i t} \Delta_{i t} k_{i t}^{\alpha} h_{i t}^{\beta}\left(Z_{\rho i t} k_{\rho i t}^{\alpha} h_{\rho i t}{ }^{\beta}\right)^{\gamma}
$$


With these neighboring effects, when physical and human capital increase, the rate of return will be $(\alpha+\beta)(1+\gamma)$. The spillover effects grow as the returns to capital and human capital grow. Consequently, the growth rate of $y_{i t}$ can be expressed as

$$
g_{y}=g_{z}+\alpha g_{k}+\beta g_{h}+\gamma\left(g_{\rho Z}+\alpha g_{\rho k}+\beta g_{\rho h}\right)
$$

\section{Appendix 2. Spatial Analysis}

To justify the inclusion of the spatial component in the model, i.e. if one region shows an influence of neighboring regions, we run the Global Moran's I test, the Global Geary's C test, the Global Getis and Ord's G test and the Pesaran test for cross-sectional dependency. They all reject the null hypothesis of absence of spatial autocorrelation, such that we can confirm the presence of spatial dependency. To determine the type of spatial dependency, we run the Lagrange Multiplier (LM) tests as well as further Wald tests and conclude that the spatial component is given by a spatial lag of the dependent variable. This leaves us with a Spatial Lag Model.

The spatial component is introduced by a $W$-matrix which is a binary contiguity weight matrix which is then multiplied with to state GDP per capita in surrounding states $\left(y_{j t}\right)$ to the incumbent. The elements of the $W$-matrix are $w_{i j}=1$ when two states share a common border and $w_{i j}=0$ otherwise. This matrix is then standardized as is the usual case in the literature, such that the sum of each row of the matrix equals to 1 .

The results of the spatial analysis can be found in table A4. 
Figure A1

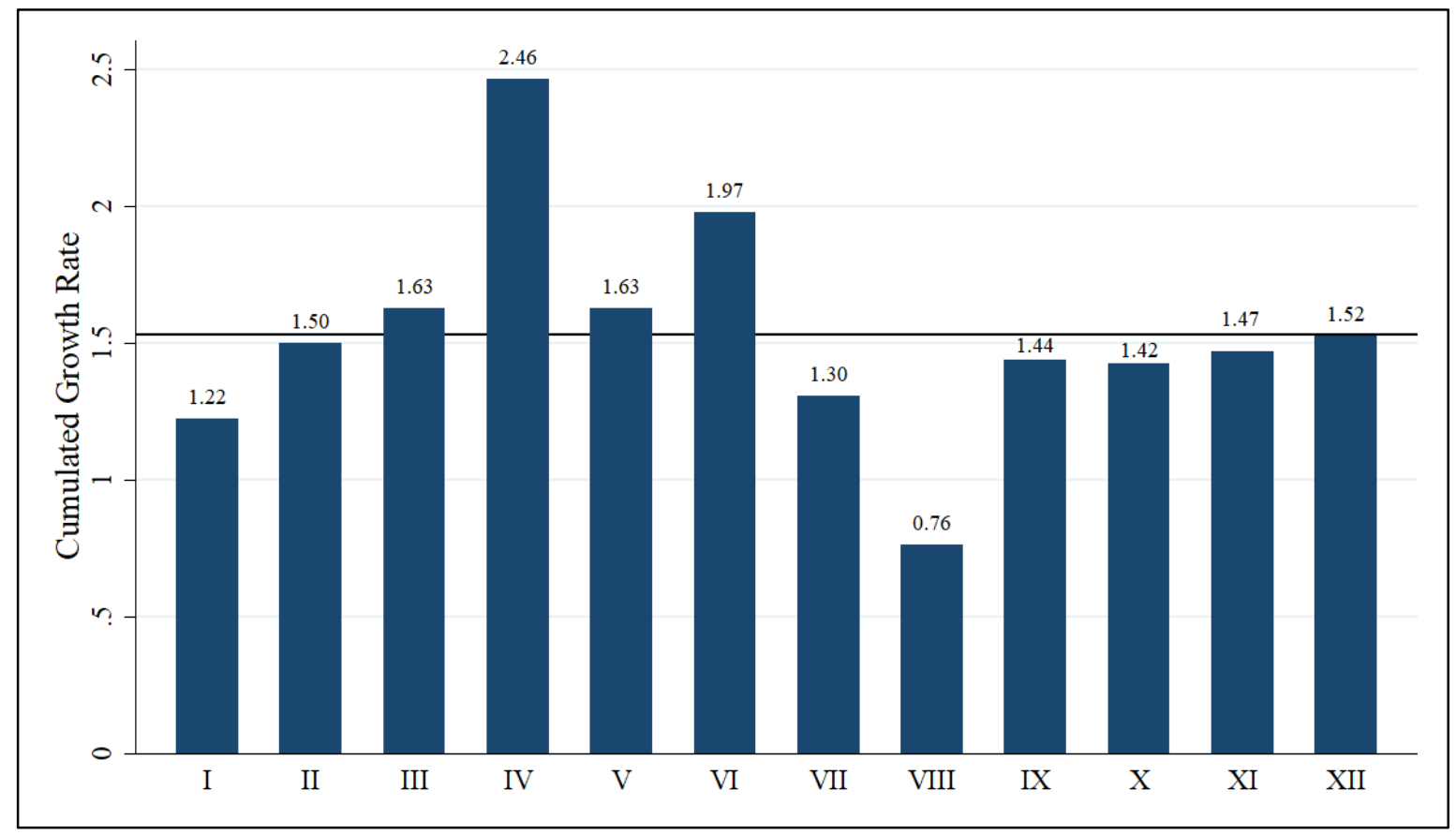

Note: The horizontal line marks the average growth rate of all military regions (152\%) during the period. 
Figure A2a

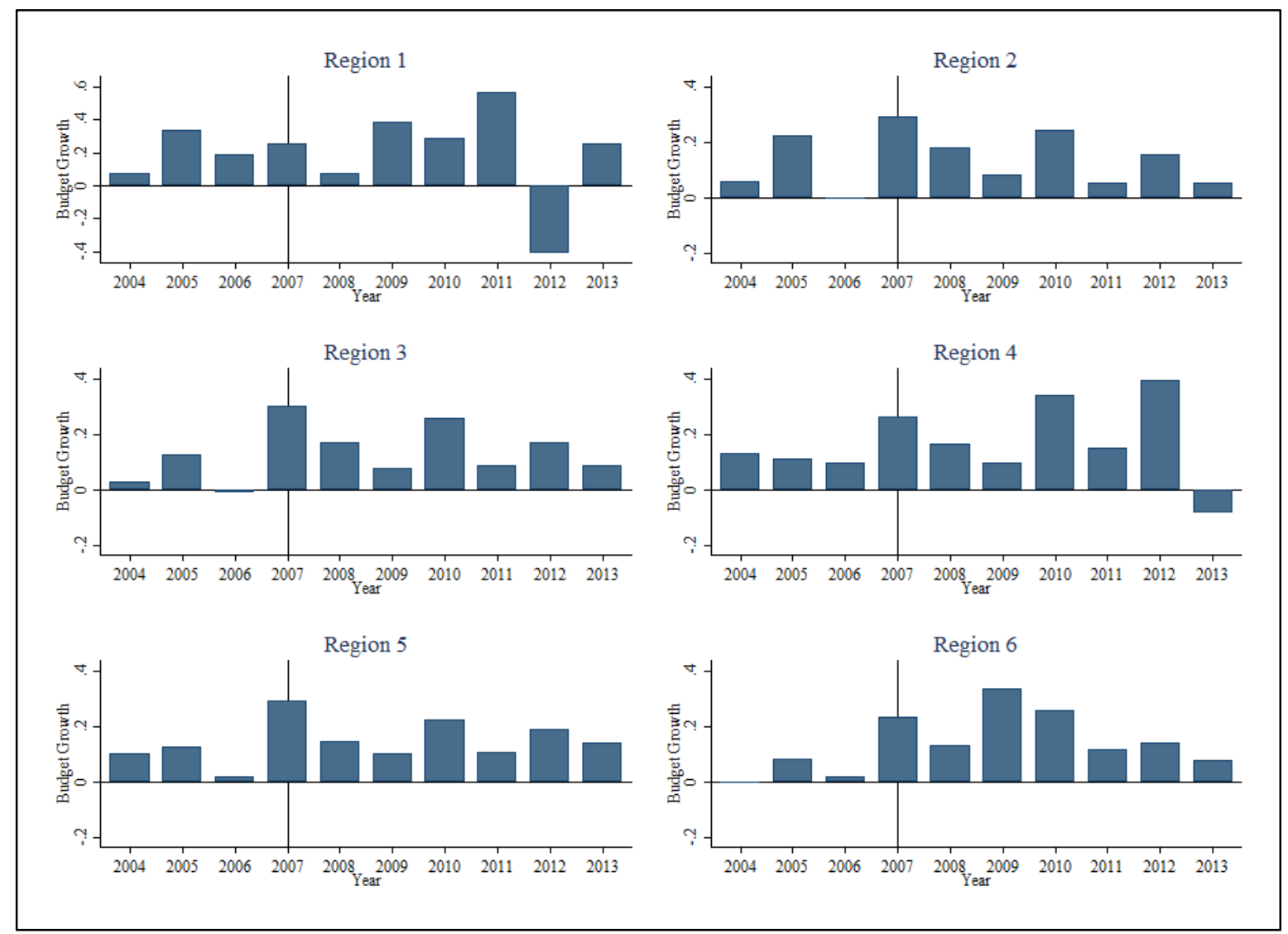

Source: Based on data from INEGI and PEF. 
Figure A2b

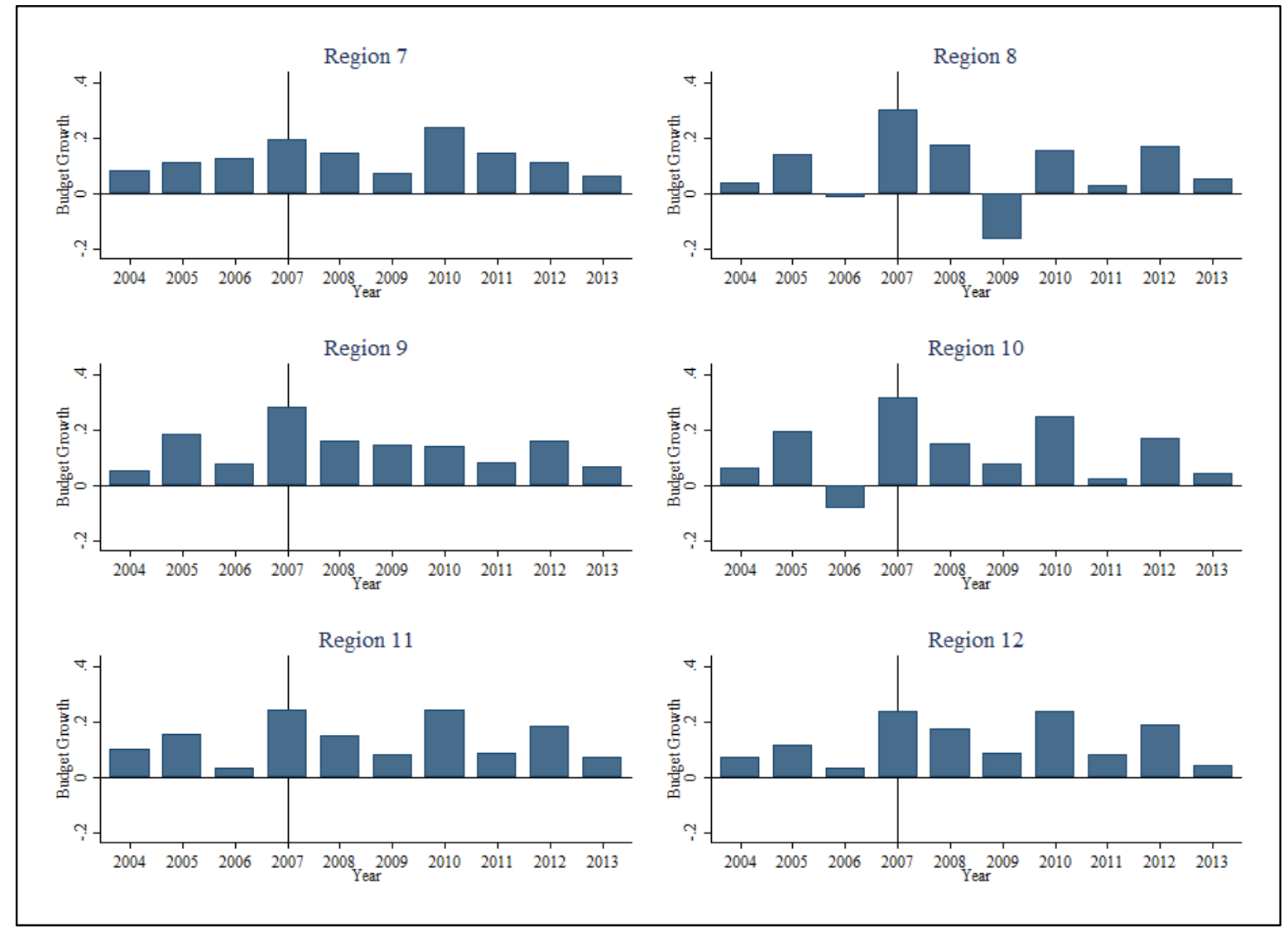

Source: Based on data from INEGI and PEF. 
Figure A3

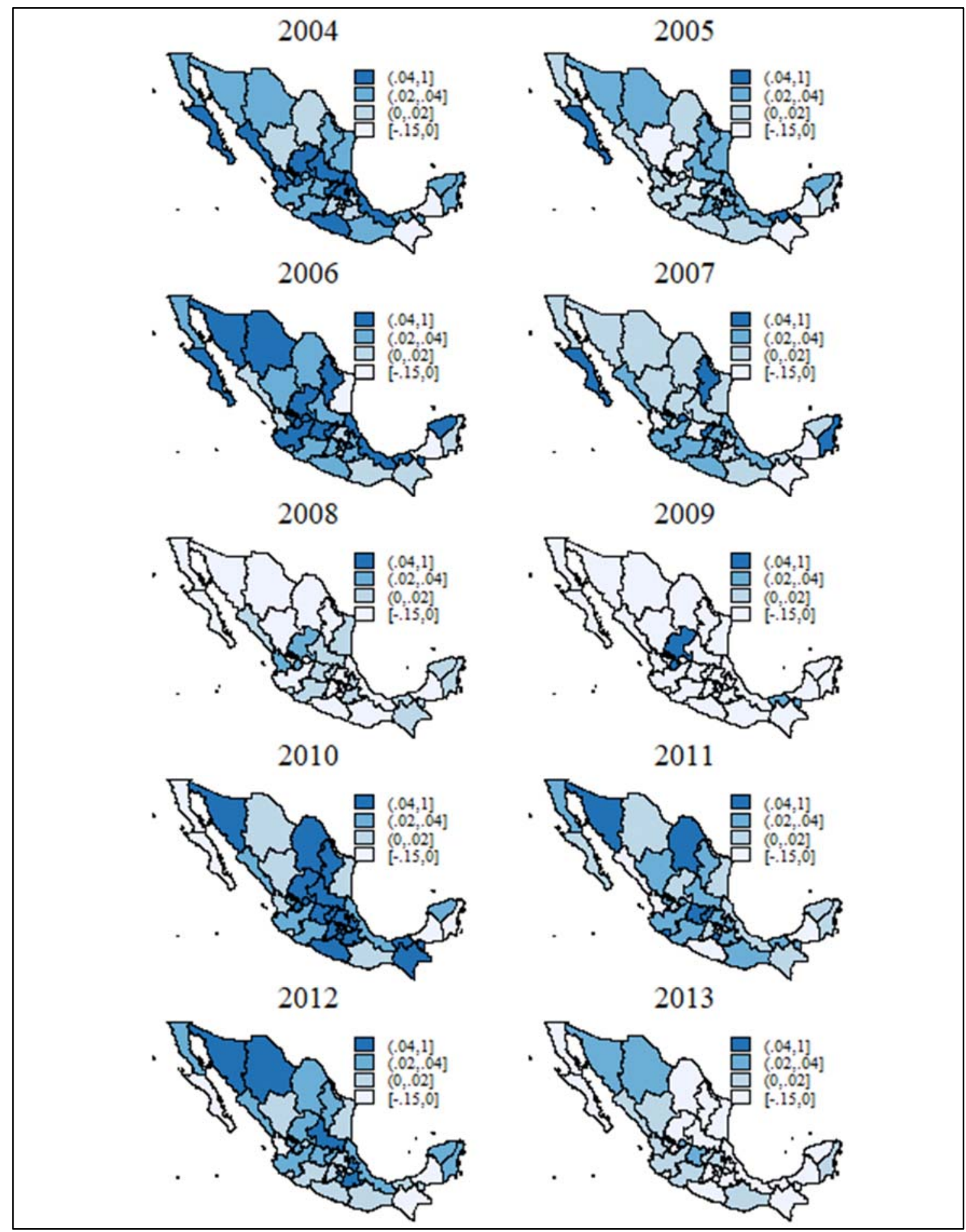

Source: Data for the maps from INEGI, CONAPO and CONABIO. 
Table A1: Descriptive Statistics of the Allocation Variables for the Military Budget

\begin{tabular}{lccccc}
\hline Variable & Mean & Std. Dev. & Min. & Max. & Obs. \\
\hline Detained People & 892.38 & $1,313.89$ & 5 & 9,483 & 320 \\
Previous Investigations & $4,534.22$ & $6,037.47$ & 491 & 37,025 & 320 \\
Seized Vehicles & 413.61 & 667.47 & 1 & 4,563 & 320 \\
PAN Voters & 402,934 & 360,092 & 9,702 & $1,460,931$ & 320 \\
\hline
\end{tabular}


Table A2: Correlation Matrix

\begin{tabular}{|c|c|c|c|c|c|c|c|c|c|c|c|c|c|c|c|c|c|}
\hline & & (1) & (2) & (3) & (4) & (5) & (6) & (7) & (8) & (9) & (10) & (11) & (12) & (13) & (14) & (15) & (16) \\
\hline (1) & Log of State GDP p.c. & 1.000 & & & & & & & & & & & & & & & \\
\hline (2) & Log of Physical Capital & 0.397 & 1.000 & & & & & & & & & & & & & & \\
\hline (3) & Log of Human Capital & 0.569 & 0.326 & 1.000 & & & & & & & & & & & & & \\
\hline (4) & Population Growth Rate & 0.239 & -0.095 & 0.310 & 1.000 & & & & & & & & & & & & \\
\hline$(5)$ & Financial Crisis & -0.014 & -0.015 & -0.001 & 0.145 & 1.000 & & & & & & & & & & & \\
\hline (6) & Log of MB (Detained People) & 0.163 & 0.108 & 0.193 & -0.381 & -0.025 & 1.000 & & & & & & & & & & \\
\hline (7) & Log of MB (Seized Vehicles) & 0.044 & -0.028 & 0.079 & -0.418 & -0.030 & 0.873 & 1.000 & & & & & & & & & \\
\hline (8) & Log of MB (Investigations) & 0.063 & -0.011 & 0.149 & -0.424 & -0.068 & 0.848 & 0.807 & 1.000 & & & & & & & & \\
\hline (9) & Log of MB (PAN Voters) & 0.012 & 0.113 & 0.119 & -0.576 & -0.092 & 0.737 & 0.708 & 0.834 & 1.000 & & & & & & & \\
\hline (10) & Log of Homicide Rate & 0.011 & -0.260 & 0.052 & -0.105 & -0.027 & 0.302 & 0.273 & 0.277 & 0.230 & 1.000 & & & & & & \\
\hline (11) & Log of Kidnapping Rate & 0.043 & -0.074 & 0.101 & -0.091 & 0.100 & 0.341 & 0.318 & 0.284 & 0.249 & 0.564 & 1.000 & & & & & \\
\hline (12) & Log of Extortion Rate & 0.089 & -0.215 & 0.107 & -0.067 & 0.062 & 0.275 & 0.281 & 0.345 & 0.355 & 0.096 & 0.350 & 1.000 & & & & \\
\hline (13) & Log of Car Robbery Rate & 0.325 & 0.041 & 0.451 & 0.085 & 0.061 & 0.218 & 0.164 & 0.168 & 0.177 & 0.536 & 0.467 & 0.163 & 1.000 & & & \\
\hline (14) & Log of Aggravated Robbery Rate & 0.340 & 0.099 & 0.509 & 0.034 & -0.039 & 0.348 & 0.249 & 0.354 & 0.356 & 0.405 & 0.446 & 0.251 & 0.515 & 1.000 & & \\
\hline$(15)$ & Log of Property Crime Rate & 0.149 & -0.326 & 0.027 & 0.299 & 0.021 & -0.101 & -0.041 & 0.006 & -0.124 & -0.196 & 0.018 & 0.335 & 0.187 & 0.206 & 1.000 & \\
\hline (16) & Log of Fraud Rate & -0.044 & -0.266 & 0.080 & 0.187 & -0.008 & -0.087 & -0.007 & 0.005 & -0.101 & -0.165 & 0.020 & 0.235 & 0.179 & 0.239 & 0.815 & 1.000 \\
\hline
\end{tabular}

Note: MB stands for the military budget allocated according to the indicator in parentheses 
Table A3: Auxiliary Estimation Using Difference GMM

\begin{tabular}{|c|c|c|c|c|}
\hline & (1) & (2) & (3) & (4) \\
\hline Dep. Var.: & $\log$ of $M B$ & $\log$ of $M B$ & Log of MB & Log of MB \\
\hline Log of State GDP p.c. & (Detained People) & (Seized Vehicles) & (Investigations) & (PAN Voters) \\
\hline \multirow[t]{2}{*}{ Log of State GDP p.c. } & 3.122 & 4.388 & -2.391 & 0.636 \\
\hline & $(4.956)$ & $(7.688)$ & $(3.303)$ & $(5.270)$ \\
\hline \multirow[t]{2}{*}{ Log of State GDP p.c. (t-1) } & 1.942 & 3.203 & -3.224 & -2.665 \\
\hline & $(9.428)$ & $(6.433)$ & $(4.767)$ & $(4.970)$ \\
\hline \multirow[t]{2}{*}{ Log of State GDP p.c. (t-2) } & -3.134 & -5.680 & 5.905 & 5.370 \\
\hline & $(8.076)$ & $(8.026)$ & $(5.010)$ & $(5.297)$ \\
\hline Observations & 256 & 256 & 256 & 256 \\
\hline Number of States & 32 & 32 & 32 & 32 \\
\hline Number of Instruments & 7 & 7 & 7 & 7 \\
\hline $\mathrm{Chi}^{2}$ of the Wald Test & 0.447 & 0.796 & $6.379^{*}$ & $12.66 * * *$ \\
\hline $\operatorname{AR}(1)$ & 0.331 & -0.0715 & 0.359 & -0.407 \\
\hline $\operatorname{AR}(2)$ & 1.421 & -0.362 & -0.988 & 0.503 \\
\hline Hansen Test p-value & 0.368 & 0.454 & 0.336 & 0.356 \\
\hline
\end{tabular}

Note: Dependent variable: approximated Military Budget. MB is the military budget based on the allocation variable in parentheses. Robust standard errors in parentheses. ${ }^{* * *} \mathrm{p}<0.01,{ }^{* *} \mathrm{p}<0.05,{ }^{*} \mathrm{p}<0.1$. 
Table A4: Results for the Spatial Autoregressive Difference GMM Estimation

\begin{tabular}{|c|c|c|c|}
\hline $\begin{array}{c}\text { Dep. Var.: } \\
\text { Log of State GDP p.c. }\end{array}$ & $\begin{array}{c}(1) \\
\text { Difference } \\
\text { GMM } \\
\end{array}$ & $\begin{array}{c}(2) \\
\text { Difference } \\
\text { GMM }\end{array}$ & $\begin{array}{c}(3) \\
\text { Difference } \\
\text { GMM }\end{array}$ \\
\hline Log of State GDP p.c. (t-1) & $\begin{array}{l}0.529 * * * \\
(0.0191)\end{array}$ & $\begin{array}{c}0.483 * * * \\
(0.0261)\end{array}$ & $\begin{array}{l}0.511 * * * \\
(0.0189)\end{array}$ \\
\hline Log of Physical Capital & $\begin{array}{l}0.275 * * * \\
(0.0220)\end{array}$ & $\begin{array}{l}0.301 * * * \\
(0.0232)\end{array}$ & $\begin{array}{l}0.285 * * * \\
(0.0224)\end{array}$ \\
\hline Log of Human Capital & $\begin{array}{l}0.226 * * * \\
(0.0410)\end{array}$ & $\begin{array}{l}0.135 * * * \\
(0.0488)\end{array}$ & $\begin{array}{l}0.254 * * * \\
(0.0513)\end{array}$ \\
\hline Population Growth Rate & $\begin{array}{l}1.791 * * \\
(0.696)\end{array}$ & $\begin{array}{l}1.076^{*} \\
(0.570)\end{array}$ & $\begin{array}{l}1.361 * * \\
(0.594)\end{array}$ \\
\hline Financial Crisis & $\begin{array}{l}-0.0282 * * * \\
(0.00224)\end{array}$ & $\begin{array}{l}-0.0260 * * * \\
(0.00179)\end{array}$ & $\begin{array}{c}-0.0271 * * * \\
(0.00201)\end{array}$ \\
\hline Log of Homicide Rate & $\begin{array}{c}-0.0109 * * * \\
(0.00183)\end{array}$ & & $\begin{array}{c}-0.00890 * * * \\
(0.00214)\end{array}$ \\
\hline Log of MB (Detained People) & & $\begin{array}{c}0.00516^{* * *} \\
(0.00123)\end{array}$ & $\begin{array}{c}0.00403 * * * \\
(0.00145)\end{array}$ \\
\hline $\mathrm{W} *$ Log of GDP p.c. (i-1) & $\begin{array}{l}0.333 * * * \\
(0.0371)\end{array}$ & $\begin{array}{l}0.288 * * * \\
(0.0238) \\
\end{array}$ & $\begin{array}{l}0.322 * * * \\
(0.0368) \\
\end{array}$ \\
\hline Observations & 288 & 288 & 288 \\
\hline Number of States & 32 & 32 & 32 \\
\hline Number of Instruments & 41 & 41 & 42 \\
\hline $\mathrm{Chi}^{2}$ of the Wald Test & $40,915 * * *$ & $27,123 * * *$ & $36,918 * * *$ \\
\hline Sargan Test p-value & 0.9314 & 0.9286 & 0.9551 \\
\hline
\end{tabular}

Note: Dependent variable: Log of State GDP per capita. MB is the military budget allocated by the rate of detained people. Robust standard errors in parentheses. $* * * \mathrm{p}<0.01, * * \mathrm{p}<0.05, * \mathrm{p}<0.1$. 